\title{
The European storm Kyrill in January 2007: synoptic evolution, meteorological impacts and some considerations with respect to climate change
}

\author{
A. H. Fink, T. Brücher, V. Ermert, A. Krüger, and J. G. Pinto \\ Institute for Geophysics and Meteorology, University of Cologne, Germany \\ Received: 20 May 2008 - Revised: 4 November 2008 - Accepted: 11 February 2009 - Published: 19 March 2009
}

\begin{abstract}
The synoptic evolution and some meteorological impacts of the European winter storm Kyrill that swept across Western, Central, and Eastern Europe between 17 and 19 January 2007 are investigated. The intensity and large storm damage associated with Kyrill is explained based on synoptic and mesoscale environmental storm features, as well as on comparisons to previous storms. Kyrill appeared on weather maps over the US state of Arkansas about four days before it hit Europe. It underwent an explosive intensification over the Western North Atlantic Ocean while crossing a very intense zonal polar jet stream. A superposition of several favourable meteorological conditions west of the British Isles caused a further deepening of the storm when it started to affect Western Europe. Evidence is provided that a favourable alignment of three polar jet streaks and a dry air intrusion over the occlusion and cold fronts were causal factors in maintaining Kyrill's low pressure very far into Eastern Europe.

Kyrill, like many other strong European winter storms, was embedded in a pre-existing, anomalously wide, northsouth mean sea-level pressure (MSLP) gradient field. In addition to the range of gusts that might be expected from the synoptic-scale pressure field, mesoscale features associated with convective overturning at the cold front are suggested as the likely causes for the extremely damaging peak gusts observed at many lowland stations during the passage of Kyrill's cold front. Compared to other storms, Kyrill was by far not the most intense system in terms of core pressure and circulation anomaly. However, the system moved into a pre-existing strong MSLP gradient located over Central Europe which extended into Eastern Europe. This fact is considered determinant for the anomalously large area affected by Kyrill.
\end{abstract}

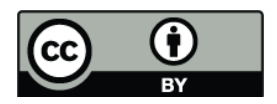

Correspondence to: A. H. Fink (fink@meteo.uni-koeln.de)
Additionally, considerations of windiness in climate change simulations using two state-of-the-art regional climate models driven by ECHAM5 indicate that not only Central, but also Eastern Central Europe may be affected by higher surface wind speeds at the end of the 21 st century. These changes are partially associated with the increased pressure gradient over Europe which is identified in the ECHAM5 simulations. Thus, with respect to the area affected, as well as to the synoptic and mesoscale storm features, it is proposed that Kyrill may serve as an interesting study case to assess future storm impacts.

\section{Introduction}

Mid-latitude winter storms rank, after tropical cyclones, as the second highest cause of insurance loss related to a natural disaster, and are the most frequent and costly natural hazards for Central Europe (e.g., Swiss Re, 2000). The relevance of such storms in terms of insured damage is enormous: for example, the three storms during December 1999, Anatol, Lothar, and Martin (storm names employed herein are as used by the German Weather Service, DWD) caused a total insured loss exceeding 10 billion Euro across Europe, while the total economic loss were twice as much (MunichRe, 2001; Deutsche Rück, 2005). Individual meteorological factors that favour the development of strong extratropical cyclones over the Eastern North Atlantic Ocean and that steer these powerful storms to Central Europe are wellknown: an enhanced north-south tropospheric temperature contrast associated with a very strong upper-tropospheric jet stream directed towards Europe (e.g., Ulbrich et al., 2001; Wernli et al., 2002), upper-level divergence at the left exit region of the jet stream, sometimes augmented by the colocated right entrance region of a downstream second jet streak (e.g., Uccellini and Johnson, 1979; Baehr et al., 1999), upper-level dry air intrusions overrunning existing frontal

Published by Copernicus Publications on behalf of the European Geosciences Union. 
structures (e.g., Uccellini, 1990; Browning, 1997; Young and Grahame, 1999), and the inclusion of anomalously warm and humid air in the warm sector of the cyclone (e.g., Chang et al., 1984). Pinto et al. (2009) demonstrated that a strong intensification of Atlantic cyclones is frequently linked to the occurrence of extreme values of the above-mentioned growth factors in the immediate vicinity of the cyclone centre. It appears that these favourable conditions happen more frequently and persistently during positive phases of the North Atlantic Oscillation (NAO; e.g., Defant et al., 1924; Walker, 1924). The positive NAO phase is associated with an anomalously strong Icelandic Low and Azores High (e.g., Hurrell, 1995). Further, Pinto et al., 2009 provided evidence that the enhanced number of extreme cyclones in positive NAO phases can be explained by the larger area with the abovementioned suitable environmental growth conditions of midlatitude cyclones. Moreover, North Atlantic winter storms tend to be more intense and long-lived during positive NAO phases. However, extreme cyclones, as defined in Pinto et al. (2009), can also occur during negative phases of the NAO.

Given the socio-economic impact of these storms, their trends in an anthropogenically changed climate have attracted a lot of attention (e.g., Meehl et al., 2007; Christensen et al., 2007, and references therein). Many studies show evidence of a change in cyclone activity as a result of increasing greenhouse gases (for a review, see Ulbrich et al., 2009) related to an altered large-scale atmospheric circulation (e.g., Meehl et al., 2007). A major result for the Northern Hemisphere is that the total number of cyclones is slightly reduced in many global climate models, while the number of extreme storms may increase (e.g., Lambert and Fyfe, 2006; Leckebusch et al., 2006). From an European perspective, a significant increase of cyclone intensity is detected near the British Isles, at least for the ECHAM5 model (Bengtsson et al., 2006; Pinto et al., 2007b). In particular, Pinto et al. (2009) documented an increase of explosive cyclone developments close to Europe, especially for storms tracking over the North Sea into the Baltic Sea. The reduced blocking frequencies over Europe and an eastward shifted upperair jet stream are associated with these changes, which also have a strong signature on the extreme surface winds over Continental Europe (Pinto et al., 2007b). Accordingly, an enhancement of loss potentials for Europe may be expected (Leckebusch et al., 2007; Pinto et al., 2007a). Some of these above-described results are, however, not consensual: for example, even though the majority of the General Circulation Models (GCMs) included in the IPCC fourth assessment report (4AR) show an increase of synoptic activity over the North Atlantic and Europe as does ECHAM5, this is not true for some GCMs (cf. Ulbrich et al., 2008). In general, the impacts of climate change to synoptic activity seem to be sensitive to the choice of the GCM, the forcing, i.e. the scenario, and the tools chosen to identify, track, and characterise extratropical cyclones. (cf. e.g., Christensen et al., 2007; Pinto et al., 2007b; Raible et al., 2008; Ulbrich et al., 2009). For an in depth review on the impact of climate change on cyclone activity, including associated uncertainties, the reader is referred to Ulbrich et al. (2009).

During the winter of July 2006, Europe was affected by a series of strong storms, particularly between late December 2006 and mid-January 2007. Between the evening of 17 January and the early hours of 19 January 2007, the most intense storm, called Kyrill, swept across Europe, bringing hurricane-force winds to many parts of Western, Central, and Eastern Europe. It left a path of death and destruction extending from the British Isles to Russia, claiming at least 46 lives (Deutsche Rück, 2008; Scheuren et al., 2008). It provoked a significant disruption of road, railway, aircraft, and ship transportation services across Europe. In Germany, Austria, the Czech Republic, and Poland a total of two million homes were left without electricity. Of note is the uprooting of 62 million trees in Central Europe, particularly spruce trees in the low mountain ranges of the Sauerand Siegerland in Central Germany. According to the German Insurance Association (GDV), storm Kyrill has caused circa 2.4 billion Euro of insured losses in Germany alone (GDV, 2007). The correspondent value for Europe is currently estimated between four and seven billion Euro (Swiss Re, 2008; MunichRe, 2008), making it the most costly winter storm since Lothar and Martin in December 1999 (Deutsche Rück, 2008). It shall be mentioned that, contrary to Lothar, Kyrill was well-predicted days in advance (e.g., Friedrich and Kratzsch, 2007). The corresponding warnings issued by the National Meteorological Services in Europe likely have prevented higher damages and fatalities.

In this paper, we will investigate in Sect. 3 the synoptic evolution of Kyrill over the North Atlantic Ocean and Europe with a special emphasis on potential meteorological factors that are instrumental in understanding the intensity of the storm. Kyrill's main characteristics and significant weather impacts over Central Europe are analysed. In Sect. 4, the strength and area of the strong surface winds associated with Kyrill will be compared to the ten strongest recent European winter storms. The question will be addressed as to whether the strength of a pre-existing ambient mean sea-level pressure (MSLP) gradient may further enhance the intensity and impacts of winter storms. In Sect. 5, projected changes of the MSLP gradient over the North Atlantic Ocean and Europe at the end of this century by a GCM will be discussed along with alterations in the intensity of damaging storms assessed by results from two regional circulation models. The data used in this study are described in Sect. 2 and inferences drawn from the Kyrill case regarding the assessment of present and future storm losses will be given in Sect. 6 .

\section{Data}

Synoptic station observations including wind gusts and radiosonde data were extracted from the 
Global Telecommunication System (GTS) of the World Meteorological Organisation (WMO). The GTS data, the METEOSAT 8 water vapour imagery $(6.2 \mu \mathrm{m})$, and the surface analyses were furnished by the DWD. Precipitation radar images were downloaded from www.wetter.com and are based on data from the $5.6 \mathrm{GHz} \mathrm{C}$-band radar network of the DWD. Weather charts over North America were obtained from the California Regional Weather Server (http://virga.sfsu.edu) and the Unisys Weather Information Services (http://weather.unisys.com). Analyses and forecasts from the European Centre for Medium-Range Weather Forecasts (ECMWF), transformed from spherical harmonic space (T799) onto a $0.25^{\circ} \times 0.25^{\circ}$ latitude/longitude grid, were utilized. The first generation of the National Centers for Environmental Prediction (NCEP-1, Kalnay et al., 1996) reanalyses at T62 spectral resolution available on a $2.5^{\circ} \times 2.5^{\circ}$ latitude/longitude mesh were employed to compare the environmental atmospheric conditions in which Kyrill was embedded to the 1958-2005 climatology as well as to relate Kyrill to historical storms. The ECMWF and NCEP-1 reanalyses were available at 6-hourly intervals.

Further, ocean-atmosphere coupled GCM simulations performed with the ECHAM5/MPI-OM1 (hereafter ECHAM5; cf. Roeckner et al., 2003, 2006, and references therein) are considered. We analyse three ensemble simulations for the recent climate (denoted 20C), which were initialised at three different model years of the pre-industrial control simulation (500 years with fixed 1860 greenhouse gas concentrations). Furthermore, we consider three ensemble simulations for the 21st century following the IPCC SRES (Intergovernmental Panel on Climate Change Special Report on Emission Scenarios) A1B scenario (Nakićenović et al., 2000) which were started at the end of each of the three $20 \mathrm{C}$ runs. The GCM was run at T63 spectral resolution (ca. $1.875^{\circ}$ latitude-longitude), and data is available every $6 \mathrm{~h}$. These simulations have been investigated by the authors for changes of synoptic activity and surface winds with increasing greenhouse gas forcing in previous studies (e.g., Pinto et al., 2007a,b, 2009). Here, we analyse the changes of the MSLP and of the MSLP gradient. The MSLP gradient has been calculated from the gridded MSLP fields by means of a standard, fourth-order centred differences scheme for planetary grids (cf. Sanderson and Brassington, 2002). Simulations with the Regional Model (REMO; see Jacob, 2001; Jacob et al., 2007) and the German community regional climate model COSMO-CLM (Consortium for Small-scale Modelling-Climate Version of the Lokal-Modell; cf. Böhm et al., 2006) nested into the above-mentioned ECHAM5 simulations were also diagnosed. REMO possesses a grid resolution of about $10 \mathrm{~km}\left(0.088^{\circ}\right.$ latitude/longitude $)$ whereas COSMO-CLM has a grid size of about $20 \mathrm{~km}\left(0.165^{\circ}\right.$ latitude/longitude).

Due to data availability, only one regional simulation per scenario is considered. The REMO and COSMO-CLM data was used to compute statistics of the changes in the daily 10-m maximum wind speed between 1970-1999 and 20702099.

\section{Synoptic development and meteorological impacts}

In this section, a brief survey of the circulation in the Atlantic-European sector of the Northern Hemisphere will be provided and the synoptic evolution of storm Kyrill will be explored. Particular emphasis will be given on the roles of the upper-level jet streams, the dry air intrusion, and the vertical mixing of momentum during the passage of the cold front to understand the severity of the storm over Europe.

\subsection{General weather conditions}

The period between the end of December 2006 and midJanuary 2007 was characterised by a high frequency and rapid sequence of intense storms over the North Atlantic Ocean and Europe. The occurrence of the storms was favoured by the strong, zonally-oriented tropospheric temperature gradient over the North Atlantic Ocean and Europe, which contributed to stronger than average winds across the North Atlantic Ocean. Due to the enhanced meridional temperature contrast during this period, the upper-level flow over the North Atlantic Ocean and Western Europe was anomalously strong and oriented in a west-east, i.e., zonal direction. Averaged over the period of December 2006 to March 2007, the NAO index value was strongly positive $(+1.83)$. This is the highest value since the winter of 1999/2000 $(+1.85$; after Jones et al., 1997), updated at http://www.cru.uea.ac.uk/ $\sim$ timo/projpages/nao_update.htm). Accordingly, the blocking index (as defined by Tibaldi and Molteni, 1988) for January had very low values over Europe, even below the 5th percentile between $10^{\circ}$ and $40^{\circ} \mathrm{E}$ (not shown), indicating a clear dominance of zonal weather patterns. The MSLP for January 2007 was characterised by an anomalously strong pressure gradient over the Eastern North Atlantic Ocean and Europe (Fig. 1), particularly in a zonal strip extending from the region west of the British Isles eastward to Poland. Average January 2007 MSLP values in Northern Scandinavia were about $16 \mathrm{hPa}$ below the 1958-2005 mean, while positive MSLP anomalies reaching up to $9 \mathrm{hPa}$ were observed to the west of the Iberian Peninsula. Note that MSLP anomalies are due partly to the high frequency of storms. However, MSLP values were below normal over the polar regions and above normal in almost all parts of the subtropics, indicating a positive value of the Arctic Oscillation/Northern Annular Mode (Ogi et al., 2004) and suggesting that all incipient Atlantic winter storms in January 2007 were already embedded in a stronger, north-south pressure gradient. As a result of the persistent zonal circulation, the January of 2007 was extremely warm over Central Europe, leading to an anomaly of $+6.8^{\circ} \mathrm{C}$ with respect to the 1761-1970 mean for the long Central European temperature 

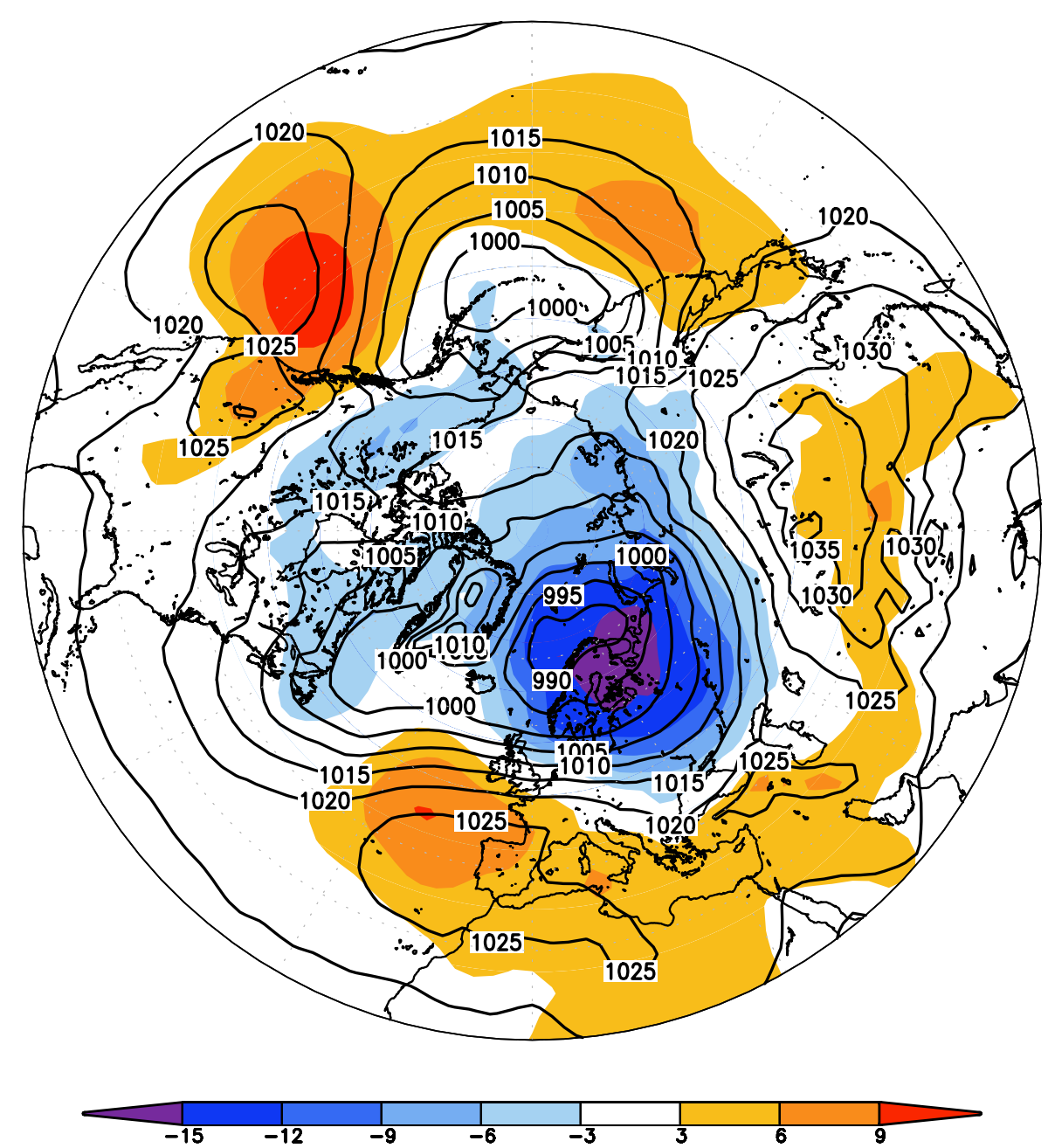

Fig. 1. Average January 2007 NCEP-1 MSLP (contours, in hPa) and its anomalies (shading, in hPa) with respect to the January 1958-2005 climatology.

time series based on data from Potsdam, De Bilt, Vienna, and Basel (cf. http://www.uni-koeln.de/math-nat-fak/ geomet/meteo/Klimastatistik/index-e.html). In fact, all the three winter months were extremely warm, making the winter of July 2006 the warmest winter in Central Europe since at least 1761/62 and perhaps since more than half a millennium (Luterbacher et al., 2007).

\subsection{Development of Kyrill over the North Atlantic Ocean}

A meticulous backward tracking of the barometric depression that later developed into storm Kyrill was carried out using both automatic and manual techniques. Results revealed that the incipient cyclonic depression, termed Kyrill I, with a core pressure of $1013 \mathrm{hPa}$ formed at a stationary, waving cold front located underneath the eastward side of an upperlevel, longwave trough over North-Eastern Arkansas (USA) between 18:00 UTC 14 January and 00:00 UTC 15 January 2007. The complete track and the MSLP core pressure values were derived using the automatic tracking algorithm based on the Laplacian of the MSLP field (cf. Murray and Simmonds, 1991; Pinto et al., 2005) and are shown in Fig. 2. It shall be emphasized that the automatic tracking method does not pick up the correct path of the depression until it reaches the mid-western states of the USA on 00:00 UTC 16 January 2007. This is related to slack pressure gradients and/or multiple MSLP centres over North America in the NCEP-1 re-analyses.

The upper-level flow steered the surface depression northeastward out on the Western North Atlantic Ocean to the southeast of Nova Scotia where it started to undergo an explosive cyclogenesis, i.e. the core pressure of Kyrill I deepened by more than $24 \mathrm{hPa}$ for example between 12:00 UTC 16 January $(998 \mathrm{hPa})$ and 12:00 UTC 17 January $2007(968 \mathrm{hPa})$. This rapid intensification was associated with the poleward crossing of the strong polar jet stream with wind speeds in excess of $200 \mathrm{kn}$ corresponding 


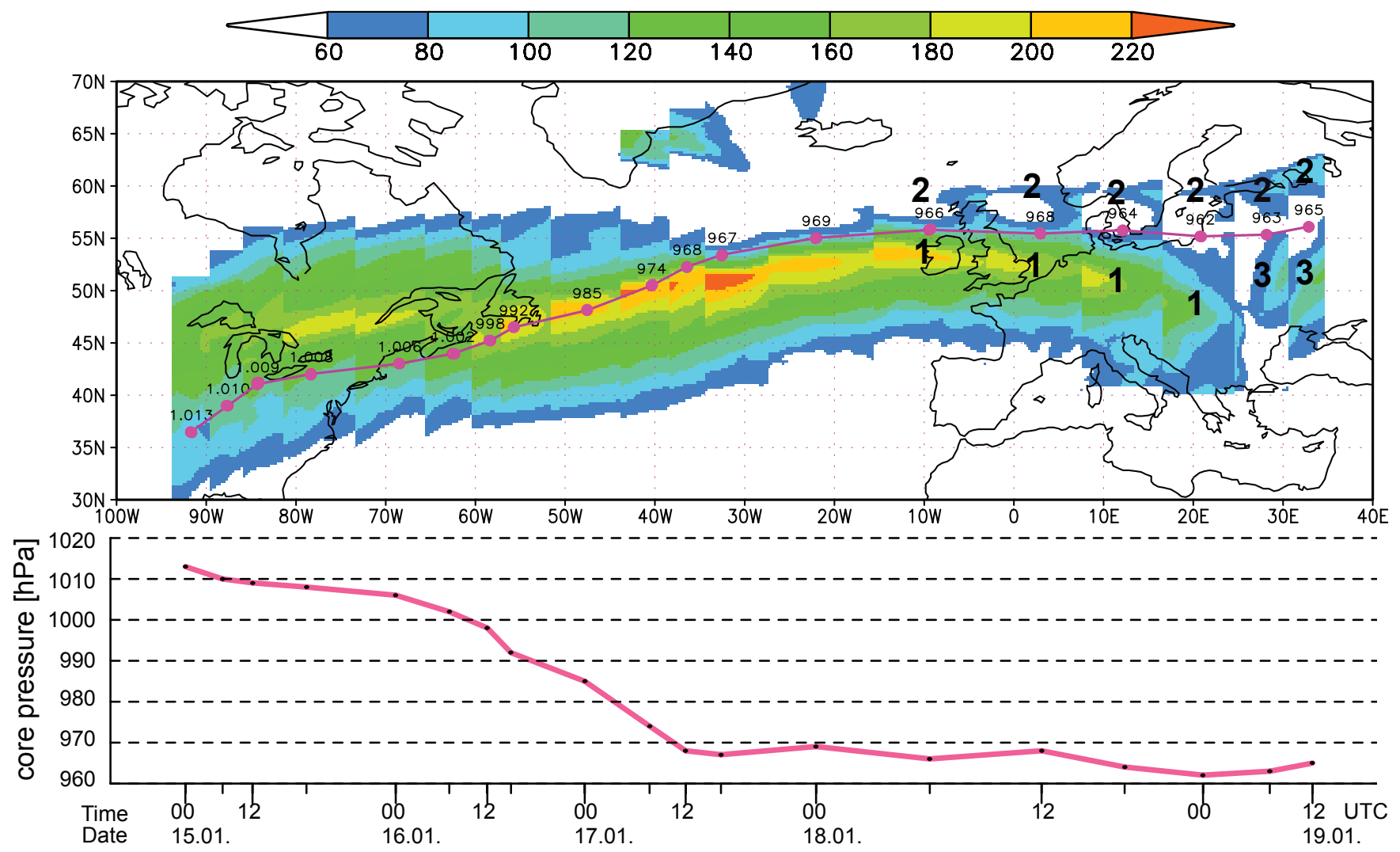

Fig. 2. Top panel shows the jet stream on the $250 \mathrm{hPa}$ pressure level (source: ECMWF). Also displayed is the surface track of Kyrill (source: NCEP-1). The corresponding core MSLP values are given in the bottom panel for the period 00:00 UTC 15 January to 12:00 UTC 19 January 2007. The jet stream is shown in a six-hourly moving window centred on the position of Kyrill. The units of the colour bar are in $\mathrm{kn}$. The window possesses a time-constant latitudinal extension of $30^{\circ}$, whereas the longitudinal size was adapted to the translation speed of the storm. The split jet structure is denoted with "1", "2", and "3". For more details see text.

to $103 \mathrm{~m} \mathrm{~s}^{-1}$ (Fig. 2). However, the positioning of Kyrill I in the cold polar air mass and the associated commencement of the occlusion process on 12:00 UTC 17 January 2007 (not shown) would not have favoured a further development of Kyrill. On 00:00 UTC 18 January 2007, a secondary cyclone (termed Kyrill II) appeared in the area of the occlusion point of Kyrill I, the latter being located on the $30^{\circ} \mathrm{W}$ meridian (Fig. 3a). The rapid growth of secondary frontal waves is a common feature within North Atlantic cyclones, however, the dynamics of these often small-scale and shallow features in their incipient stage is not well understood (Parker, 1998). One large-scale factor promoting the growth of Kyrill II into the primary cyclone that attained a deeper core pressure than its parent cyclone only $12 \mathrm{~h}$ later (Fig. 3d) is the fact that Kyrill II remained close to the left exit region of the intense polar jet streak until it reached Denmark (Fig. 2 and Fig. 3b). It is well-known that upper-level divergence due to the ageostrophic circulation crosswise to the jet prevails at the cyclonic poleward side of the jet delta region, thereby supporting a rapid intensification and/or the maintenance of a low core pressure (e.g., Uccellini and Johnson, 1979; Uc- cellini, 1990). As a first result, we note that the intense polar jet over the North Atlantic Ocean, reflecting a strong tropospheric meridional temperature contrast, was instrumental in Kyrill's fast zonal translation speed directed towards Central Europe, its explosive development over the Western Atlantic, the growth of Kyrill II, and the preservation of its low core pressure when it approached Europe (cf. Sect. 3.3).

The question arises as to whether other meteorological factors have caused the further, albeit slow, deepening phase of Kyrill II over the North and Baltic Seas leading to the minimum pressure of $962 \mathrm{hPa}$ over the Baltic states on 00:00 UTC 19 January 2007 (cf. Fig. 2) ${ }^{1}$. It is suggested here that Kyrill II apparently deepened further due to a superposition of favourable conditions surrounding it, i.e.,

(a) ahead of an intensifying upper level shortwave trough (not shown), (b) underneath enhanced upper-level outflow

\footnotetext{
${ }^{1}$ The estimations of minimum central sea-level pressure for Kyrill differ between sources. For example, www.unwetterzentrale.de gives $961 \mathrm{hPa}$, www.wetterspiegel.de estimates $960 \mathrm{hPa}$, and the DWD surface analysis suggests a core pressure even below $960 \mathrm{hPa}$.
} 


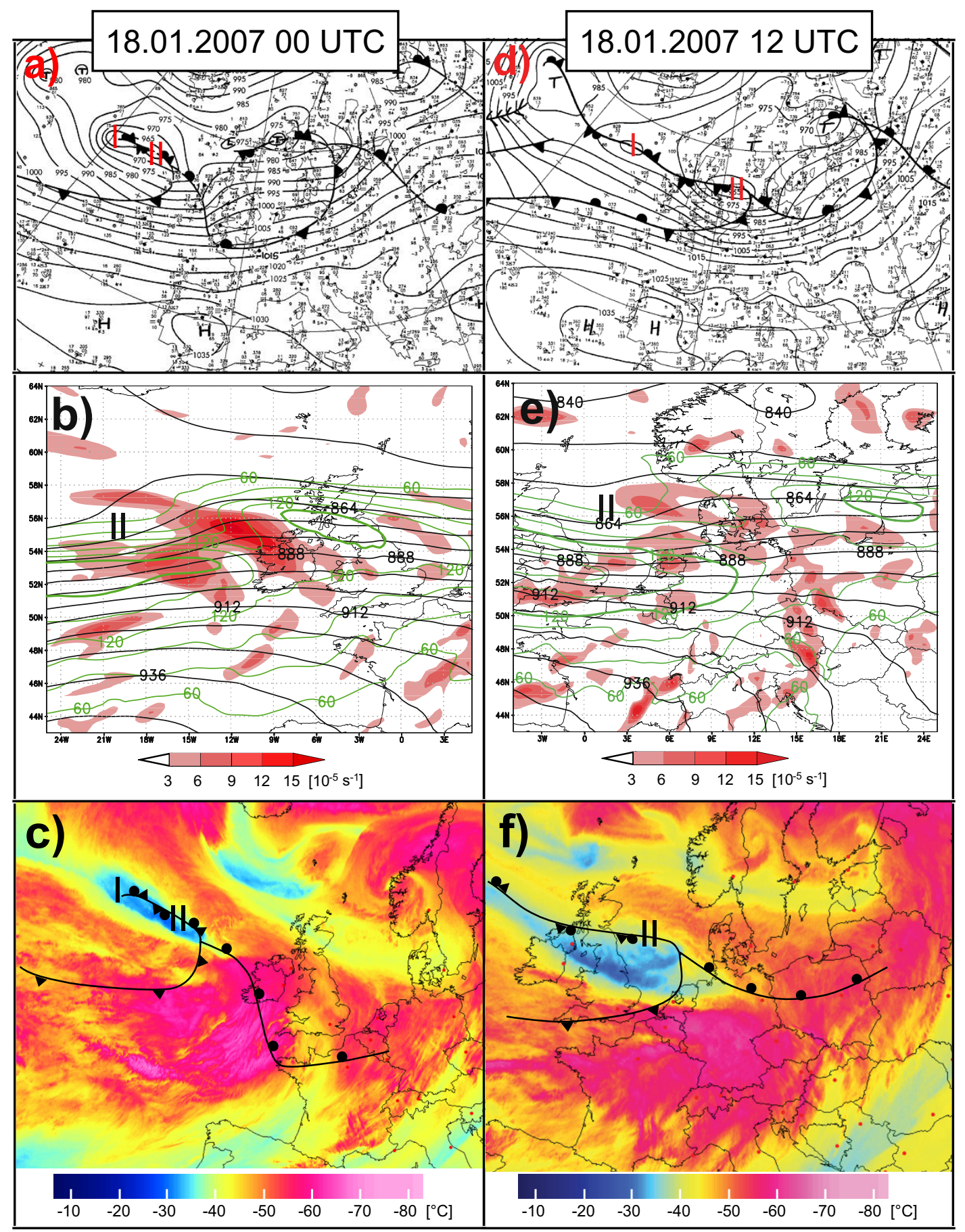

Fig. 3. 18 January 2007 for 00:00 UTC (left), 12:00 UTC (middle), and 18:00 UTC (right):(a, d, and g) Surface analysis of MSLP and fronts (source: DWD). (b, e, and h) Geopotential height (in gpdm; black lines), wind speed (in kn; green lines), and divergence (coloured) smoothed by a nine-point filter (in $10^{-5} \mathrm{~s}^{-1}$; shaded) at the $300 \mathrm{hPa}$ pressure level (source: ECMWF). (c, f, and i) METEOSAT 8 image of brightness temperatures at $6.2 \mu \mathrm{m}$. Blue (red) colours are associated with a dry (humid) middle and upper troposphere (cf. Schmetz and Turpeinen, 1988). Overlaid are the fronts of Kyrill. The Latin numbers "I" and "II" indicate the positions of Kyrill I and Kyrill II, respectively. 


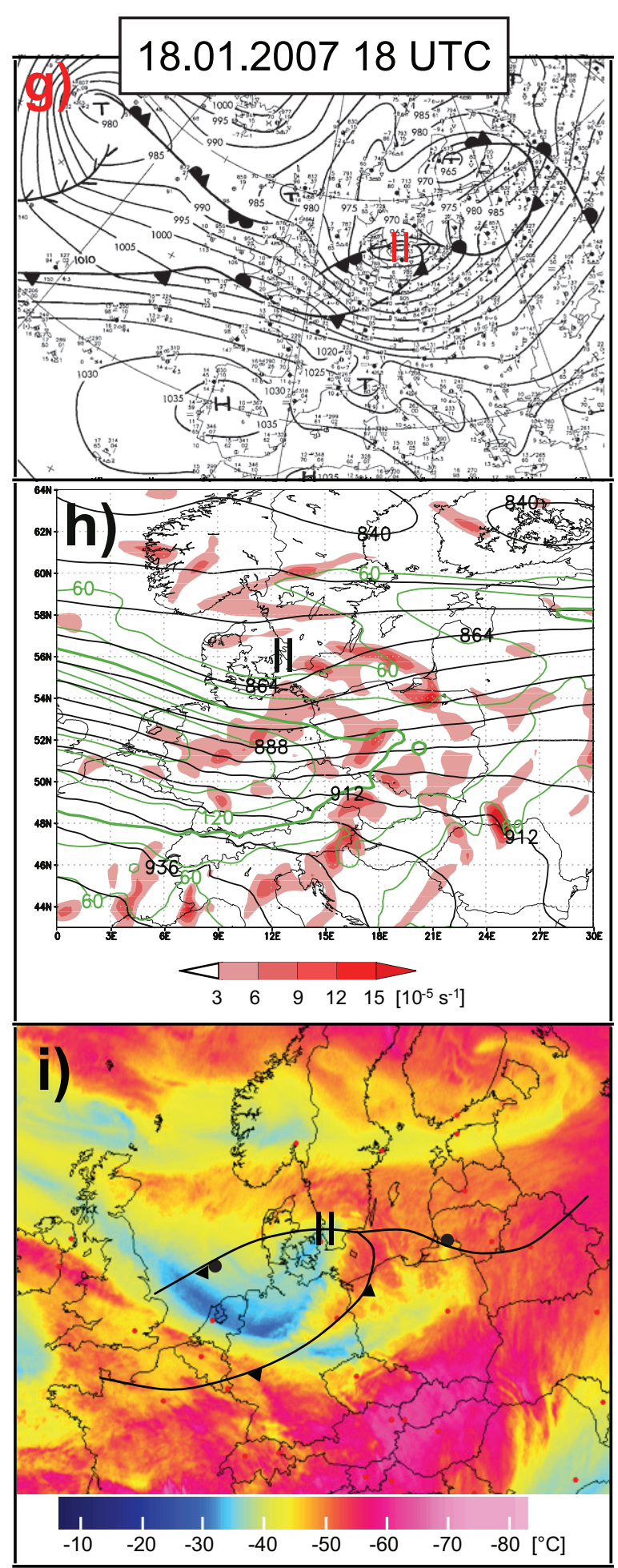

Fig. 3. Continued.

associated with the left (right) exit (entrance) region of a upstream (downstream) jet streak (cf. split jet in Fig. 3b), (c) the commencement of the intrusion of upper-level dry air over the frontal zones (Fig. 3c), and (d) by the presence of warm and humid air masses, classified as a maritime tropical air mass by the Berliner Wetterkarte (2007), in the warm sector of the low.

In association with the low core pressure, a remarkable pressure gradient of more than $70 \mathrm{hPa}$ developed between Kyrill II's centre over the North Sea and an anticyclone over the Iberian Peninsula on 12:00 UTC 18 January 2007 (Fig. 3d). Note the tight pressure contours extending over a distance of about $1000 \mathrm{~km}$ between the Alps and the Central North Sea, where Kyrill II's core is located. As we will see below, Kyrill II was characterised by an unusual large meridional extension of a strong pressure gradient and gale force winds.

\subsection{Development of Kyrill over Central Europe}

In this Section, the questions will be addressed what caused the core pressure of Kyrill II to remain very low when it moved towards Eastern Europe. Figure 3d and e clearly depict that the surface pressure centre of Kyrill II over the Western North Sea moves in a region of upper-level divergence over the Eastern North Sea and Denmark that results from the split polar jet structure, denoted "1" and "2" in Fig. 2, with peak winds in excess of $180 \mathrm{kn}$ and $120 \mathrm{kn}$ over England and the Baltic states, respectively. The latter jet streak was a result of the enhancement of the meridional temperature gradient caused by Kyrill II's warm front, whereas the relative wind speed minimum over the German Bight (for the location, see Fig. 5) was caused by the weakening of the temperature gradient in the vicinity of the cyclone's warm sector (Fig. 3). As a consequence of its location in a delta-entrance dual jet configuration, Kyrill II benefitted from enhanced upper-level divergence (Fig. 3b, e, and h), a factor that also enhanced the development of Lothar in December 1999 (Ulbrich et al., 2001, their Fig. 4). In the next $24 \mathrm{~h}$, a third jet streak (see "3" in Fig. 2) developed ahead of the deepening shortwave trough, located over East Germany (Fig. 3h), and Kyrill II maintained its favourable location in terms of upper-level divergence now caused by the second and third jet alignment.

Besides the favourable jet pattern, the occurrence of a dry air intrusion may have delayed the weakening of the cyclone while it moved into Eastern Europe. On 00:00 UTC 18 January 2007 a dry air streak is located above Kyrill's two pressure cores (Fig. 3c). This structure was associated with the explosive cyclogenesis of Kyrill I (not shown). Figure $3 \mathrm{f}$ shows that this upper-level dry-air intrusion has farther advanced over the occlusion point and the cold front to its south on 12:00 UTC 18 January 2007. This development continues for the next hours when upper-level dry air overran the cold front of Kyrill II even farther (Fig. 3i). This fact is clearly seen by the six-hourly radiosonde launches performed at Lindenberg (Germany, $52^{\circ} 22^{\prime} \mathrm{N}, 14^{\circ} 12^{\prime} \mathrm{E}$; cf. Fig. 5). On 12:00 UTC 18 January 2007 Lindenberg was located in the 

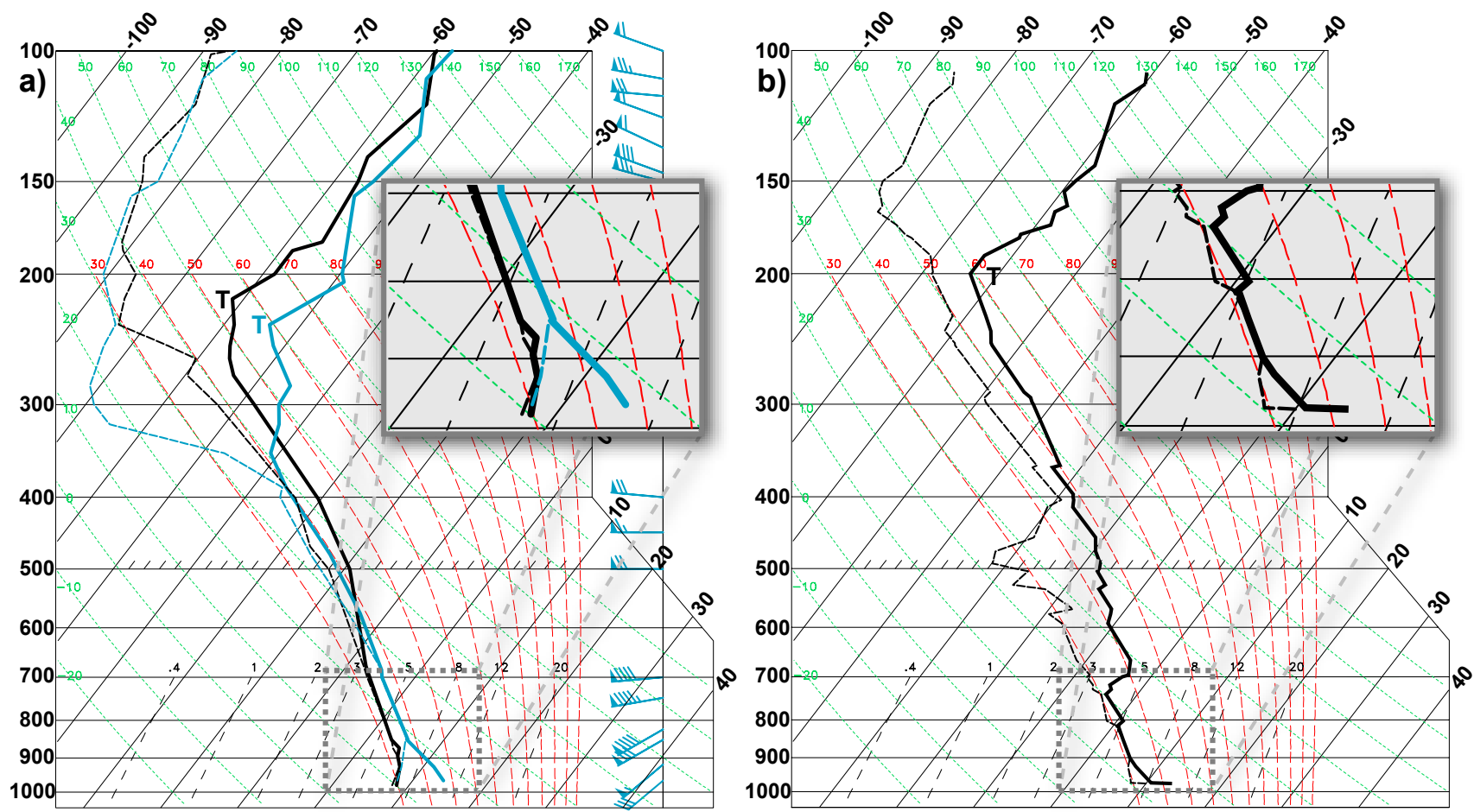

Fig. 4. Skew T-log p diagram of (a) Lindenberg (Germany, $52^{\circ} 22^{\prime} \mathrm{N}, 14^{\circ} 12^{\prime} \mathrm{E}$ ) on 12:00 UTC (black lines) and 18:00 UTC (blue lines) as well as (b) Larkhill (Great Britain; $51^{\circ} 12^{\prime} \mathrm{N}, 1^{\circ} 48^{\prime} \mathrm{W}$ ) on 12:00 UTC 18 January 2007. The solid (dashed) thick lines represent temperature (dew point) observations. The heights of the tropopause are indicated by a "T". Wind barbs are only inserted in (a) for the 18:00 UTC launch of Lindenberg. Note for (b) that the surface values at Larkhill were taken several minutes in advance of the ascent and are probably not representative for the conditions at the start of the launch at 11:26 UTC.

warm sector of Kyrill II (Fig. 4a and cf. Fig. 3f). The subsequent radiosonde was launched at 17:11 UTC, about one hour before the passage of the cold front. Consequently, the whole troposphere was passed by the balloon before the arrival of Kyrill II's cold front (cf. the strong radar echoes in Fig. 5). For this reason the troposphere is still characterised by the presence of the warm and moist air mass of Kyrill II's warm sector (e.g., $14^{\circ} \mathrm{C}$ at the surface). Unlike the 12:00 UTC sounding, dry air masses were now observed above $400 \mathrm{hPa}$ (Fig. 4a).

Consequently the dry air advection enhanced the convective instability. It is speculated here that the convective instability was released due to the lifting associated with the cold front. However, based on the Lindenberg sounding, lifting would not have resulted in free convection since the equivalent potential temperature is constant between $850 \mathrm{hPa}$ and $700 \mathrm{hPa}$ and slightly increasing above (not shown). Free convection and the release of energy would only have been possible when the dry air subsided more deeply into the troposphere (cf. Browning, 1997, his Fig. 9). There is evidence that free convection due to the dry air intrusion indeed occurred. Firstly, the warm brightness temperatures of about $-30^{\circ} \mathrm{C}$ in the water vapour satellite images (cf. Fig. $3 f$ and i) indicate that the dry air might have reached the
$500 \mathrm{hPa}$ level. The 15 -min water vapour imagery suggests that the convection was intensifying along the cold front (not shown). On 18:00 UTC 18 January 2007 the wedge-shaped, south-westward growth of the convection parallel to the cold front is identifiable above Central East Germany, i.e. between the area of the dry air above Southern East Germany and North-Western Germany (Fig. 3i). Secondly, the strong radar echoes (note the linear structure delineated by reflectivity values exceeding $54 \mathrm{dBZ}$ between the cities of Erfurt and Leipzig) associated with the passage of the cold front over Central and Eastern Germany clearly displays the strong convective activity of the cold front (Fig. 5). Finally, lightning maps (not shown) indicate that the cold front passage was frequently associated with thunderstorms, which were restricted to the area of the dry air intrusion. The lightning positioning system of the DWD recorded intensities of up to 2000 flashes per two hours (Berliner Wetterkarte, 2007).

Surface observations also imply that thunderstorms associated with the cold front passage were widespread and intense. For example, a station run by the water works of Berlin measured $25 \mathrm{~mm}$ of rainfall between 17:15 and 17:45 UTC, $11.6 \mathrm{~mm}$ of which fell in only $5 \mathrm{~min}$. There were also reports of at least two tornadic storms (e.g., Friedrich and Kratzsch, 2007) around the time of the radar picture shown 


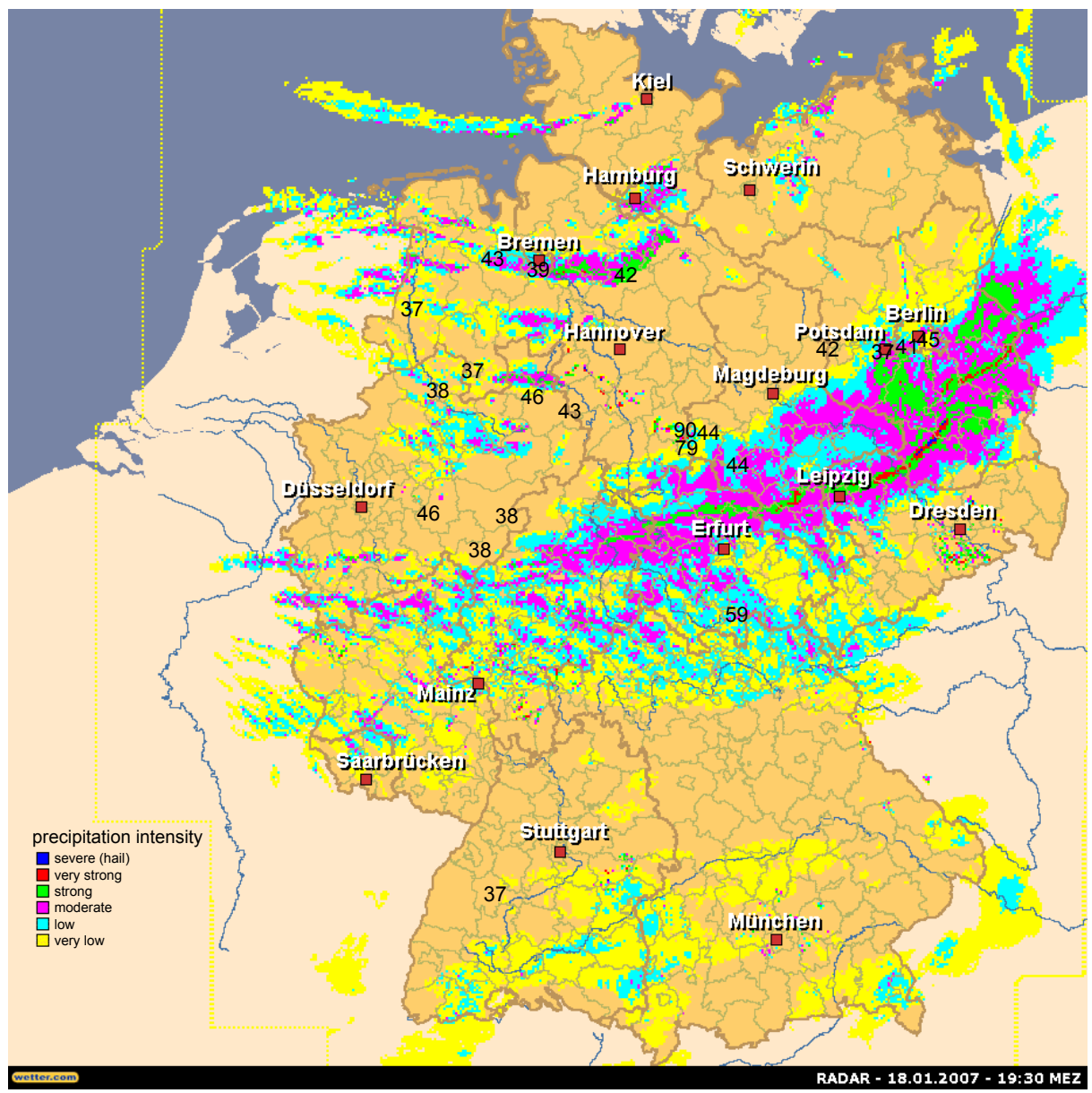

Fig. 5. Composite radar reflectivity (in dBZ) for Germany on 18:30 UTC 18 January 2007 with the top twenty 24-h precipitation amounts (in $\mathrm{mm}$ ) reported on 06:00 UTC 19 January 2007.

in Fig. 5. Also, the 24h accumulated precipitation was extraordinary. Values between 30 and $45 \mathrm{~mm}$ were frequent in the flat terrain of Northern Germany with a peak value of about $90 \mathrm{~mm}$ observed at the Brocken summit (Harz Mountains; $51^{\circ} 48^{\prime} \mathrm{N}, 10^{\circ} 37^{\prime} \mathrm{E}$; see Fig. 5). The uniqueness of the precipitation sums is understood by mentioning that they exceeded the mean January accumulations in parts of NorthEastern Germany. Additionally, the strong precipitation may have been a factor further increasing the wind damage loss. Again, the highest precipitation values were recorded in the area of the upper-level dry air (cf. Fig. 3i). In summary, it is proposed that the dry-air intrusion was instrumental for the development of the intense convection. Furthermore, it is speculated that the convection and the upper-level divergence, enhanced by the upper-level jet configuration, helped Kyrill II to maintain its unusually low core pressure when it entered the Baltic states and Western Russia.

\subsection{Observed wind gusts}

In this section we analyse what factors may have enhanced the recorded maximum gusts well beyond what might be expected from the synoptic-scale pressure gradient. Strong wind gusts were measured all over Europe. The maximum wind gusts between 00:00 UTC 17 January and 18:00 UTC 19 January 2007 are shown in Fig. 6. The strongest values of over $200 \mathrm{~km} \mathrm{~h}^{-1}$ were observed at Alpine and Tatra mountain tops. In the lowlands, a gust of $144 \mathrm{~km} \mathrm{~h}^{-1}(78 \mathrm{kn})$ was measured both at Düsseldorf airport weather station (Germany; $51^{\circ} 17^{\prime} \mathrm{N}, 6^{\circ} 47^{\prime} \mathrm{E}$, cf. Fig. 5) and Artern (Germany; $51^{\circ} 23^{\prime} \mathrm{N}, 11^{\circ} 18^{\prime} \mathrm{E}$ ). Many stations in Central and Western Europe recorded hurricane-force wind speeds in excess of $119 \mathrm{~km} \mathrm{~h}^{-1}(64 \mathrm{kn})$. A closer analysis of Fig. 6 reveals the strong station-to-station variability with respect to the maximum observed wind gusts. This could either result from macro-meteorological (i.e., orography) or micrometeorological (trees, buildings, etc.) environmental conditions of the station. However, from the flat landscape in Northern Netherlands, Germany, and Poland as well as the 


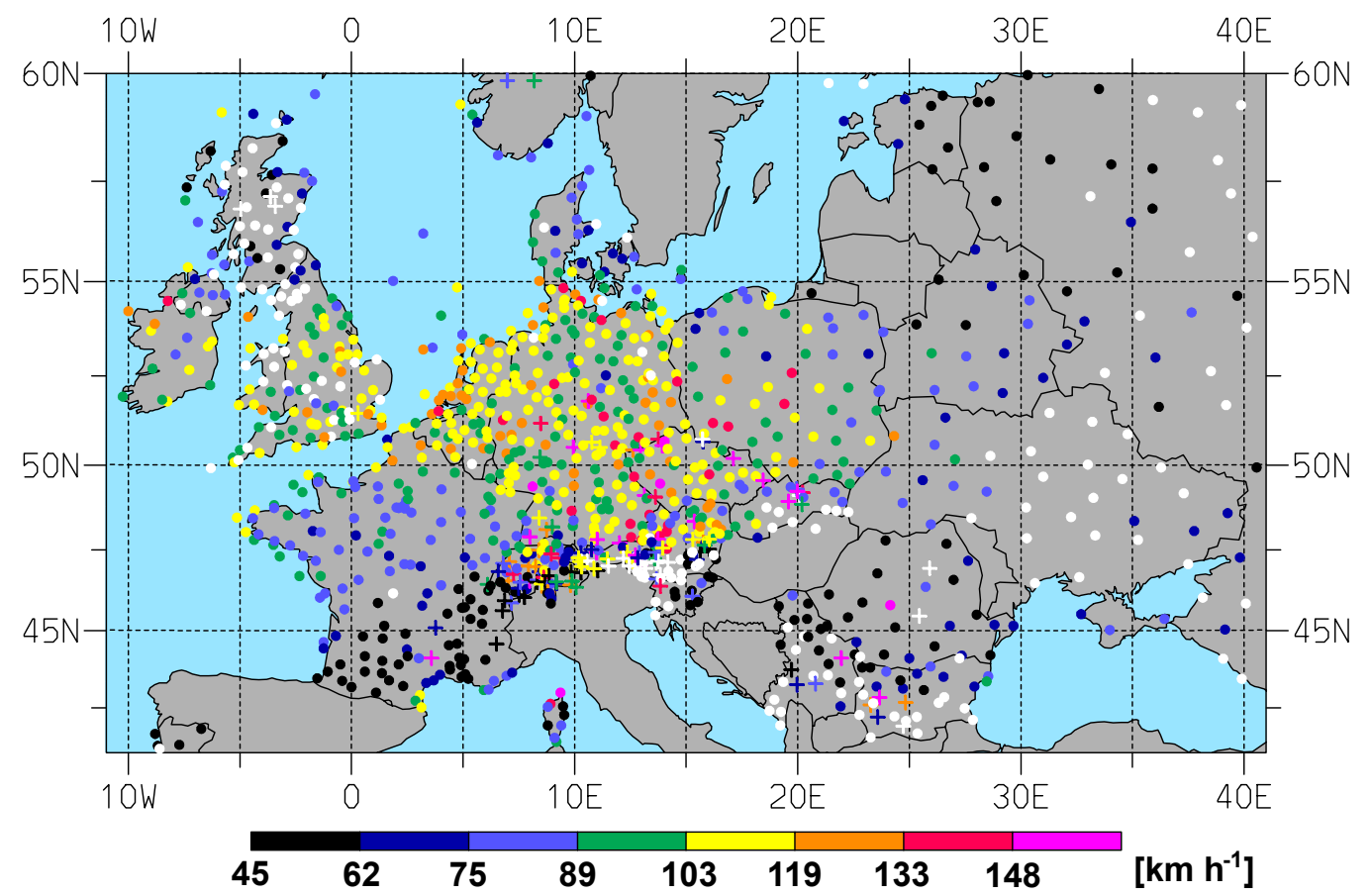

Fig. 6. Maximum wind gusts (in $\mathrm{km} \mathrm{h}^{-1}$ ) at different synoptic stations reported during the period from 00:00 UTC 17 January to 18:00 UTC 19 January 2007. Dots (crosses) delineate lowland (mountain) stations. Lowland stations possess an altitude lower than $800 \mathrm{~m}$ a.s.1. White symbols denote stations where no wind gusts were observed or reported.

synoptic conditions at the cold front we suggest that the strong variability of extreme wind gusts were associated with a downward mixing of upper-level higher wind speeds to the surface and/or the lateral spreading of convective downdrafts caused by evaporating rain in the convective storms.

Both processes are related to the sudden decrease of lowlevel static stability associated with the arrival of the cold front and strengthen the maximum wind gusts beyond the values that would result from the synoptic-scale pressure gradient. For example Kyrill II's cold front passed Lindenberg between 18 and 19:00 UTC on 18 January 2007 and is clearly seen in the hourly observations of the synoptic station (Fig. 7; cf. also the strong radar echoes at 18:30 UTC in Fig. 5). The passage of the cold front was associated with a prominent temperature (dew point) drop of about $8^{\circ} \mathrm{C}$ $\left(4^{\circ} \mathrm{C}\right)$, strong precipitation $(10.7 \mathrm{~mm}$ in one hour), a rise in MSLP, and with a turn in the wind direction between 18 and 19 UTC. Moreover, wind gustiness peaked during the arrival of the front and seems to be connected with thunderstorm activity (cf. the present weather symbols in Fig. 7). Additionally, Fig. 7 shows that the observed pre-and post-frontal wind gusts at Düsseldorf peaked at $104 \mathrm{~km} \mathrm{~h}^{-1}(56 \mathrm{kn})$, whereas the maximum gust associated with the passage of the cold front reached $144 \mathrm{~km} \mathrm{~h}^{-1}(78 \mathrm{kn})$. The observations imply that there was no deep convection and convective rainfall at Düsseldorf (Fig. 7). In contrast to North-East Germany there was no dry air above Düsseldorf during the passage of the cold front at about 17:00 UTC 18 January 2007 (cf. Fig. 3i and Fig. 7). It is therefore suggested that deep convection was suppressed in the south-western part of the cold front due to a stable stratification of the middle and upper troposphere. At this time, Düsseldorf was located in the area of the core of the strong polar jet stream (cf. Fig. 2 and Fig. 3h) and all the above mentioned facts point out that the hurricane-force wind speeds at this station were probably caused by the downward mixing of upper-level higher wind speeds. Hence, the maximum gust is a result of a destabilisation of the lower troposphere during the passage of the cold front. Unfortunately, no upper-air sounding at the nearby radiosonde station Essen was performed at the time of the cold front passage. A coincidence of the cold front passage and an ongoing vertical sounding occurred, however, at Larkhill (Great Britain; $51^{\circ} 12^{\prime} \mathrm{N}, 1^{\circ} 48^{\prime} \mathrm{W}$ ) on 12:00 UTC 18 January 2007 and the above-mentioned destabilisation of the near-surface layer can be illustrated in the corresponding skew T-log p diagram displayed in Fig. 4b. The cold air behind the surface front has intruded the lowest $3 \mathrm{~km}$ (below $700 \mathrm{hPa}$ ) and caused a dry neutral stratification below $900 \mathrm{hPa}$ and a wet neutral stability between $900 \mathrm{hPa}$ and $815 \mathrm{hPa}$. This can be inferred from the inlay in Fig. $4 \mathrm{~b}$ that enlarge the details of the sounding in the lower levels. Below $900 \mathrm{hPa}$ the vertical decrease of temperature 

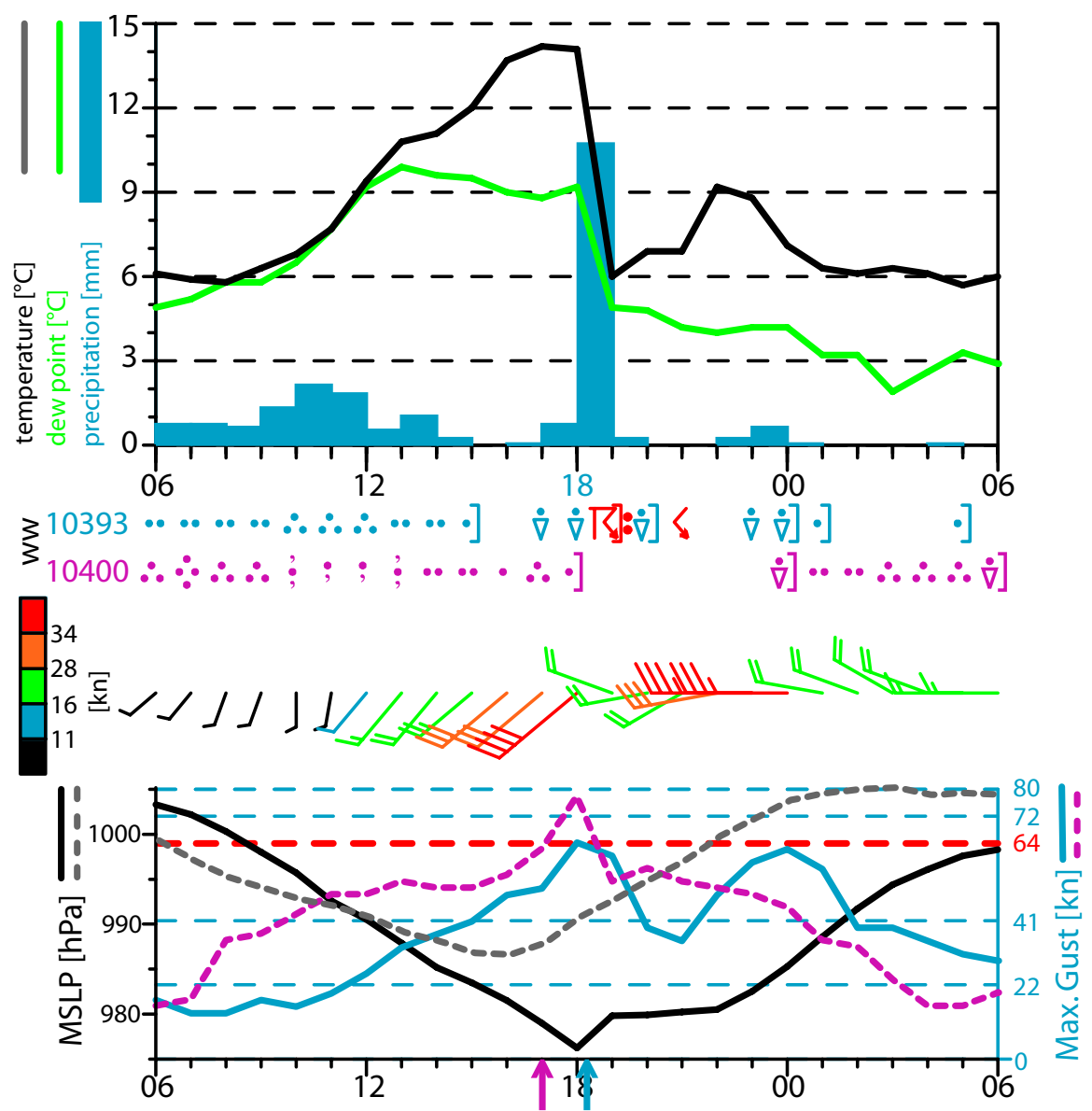

Fig. 7. Hourly surface observations from the synoptic station Lindenberg (Germany, $52^{\circ} 22^{\prime} \mathrm{N}, 14^{\circ} 12^{\prime} \mathrm{E}$; WMO station number 10393 ) for the period 06:00 UTC 18 January to 06:00 UTC 19 January 2007. Moreover, observations of present weather and maximum wind gusts are displayed in magenta for Düsseldorf (Germany; $51^{\circ} 17^{\prime} \mathrm{N}, 6^{\circ} 47^{\prime} \mathrm{E}$; WMO station number 10400$)$. (top) Temperature $\left({ }^{\circ} \mathrm{C}\right.$; black line), dew point (in ${ }^{\circ} \mathrm{C}$; green line), and precipitation amounts (in mm; blue bars). (middle) Present weather (ww; upper part) and wind barbs (in kn; lower part). (bottom) MSLP (in hPa; black lines) and maximum wind gusts during the preceding hour (in kn; Lindenberg: blue solid line, Düsseldorf: magenta dashed line). The arrows at the bottom part are indicating the estimated arrival time of Kyrill II's cold front (magenta: Düsseldorf; blue: Lindenberg).

(solid black curve) is almost parallel to the dry adiabat (green dashed line) and above this pressure level it matches the moist adiabatic lapse rate (red dashed line) within the observed stratocumulus clouds. As a consequence, no restoring force acts on an air parcel that is forced to move downward by mechanical turbulence or rain drop evaporation. Thus, higher wind speeds in the upper part of the frictional layer can easily be mixed down to the surface. Figure $4 \mathrm{~b}$ also reveals that above $700 \mathrm{hPa}$ the subtropical air mass of the warm sector of Kyrill II still existed over Larkhill and the tropopause height showed a corresponding elevated value of more than $11 \mathrm{~km}$. The discussed mesoscale frontal characteristics that augment the potential maximum gustiness will be of particular relevance when assessing storm damage in a future climate, since these mesoscale storm features are not captured by the available regional climate models.
Finally, it should be mentioned that also the strong synopticscale pressure gradient was leading to strong wind gustiness. On 00:00 UTC 19 January 2007 Kyrill II's bent-back occlusion was leading to a strengthened pressure gradient over East Germany (not shown). As a result many synoptic stations reported high maximum wind gusts also after the passage of the cold front. The station of Lindenberg, for example, observed a secondary peak of maximum wind gusts of about $115 \mathrm{~km} \mathrm{~h}^{-1}(62 \mathrm{kn})$ six hours after the passage of the cold front (Fig. 7). Note that the area of a bent-back front and cloud head may be associated with the occurence of a sting jet, a meteorological phenomenon related with damaging surface winds in the dry-slot region of extra-tropical cyclones (e.g., Browning, 2004; Browning and Field, 2004). However, from the available information, the existence of a sting jet cannot be verified in the case of Kyrill II. 
Table 1. Characteristics of historical Storm. Listed are: Storm: name of the storm; Date: date of the occurrence; gradP1: average MSLP gradient over Box $1\left(20^{\circ} \mathrm{W}-0^{\circ} \mathrm{E} ; 45^{\circ} \mathrm{N}-60^{\circ} \mathrm{N}\right.$, cf. Fig. 8) (in hPa $\left.(100 \mathrm{~km})^{-1}\right)$; gradP2: average MSLP gradient over Box $2\left(0^{\circ} \mathrm{E}-20^{\circ} \mathrm{E}\right.$; $\left.45^{\circ} \mathrm{N}-60^{\circ} \mathrm{N}\right)\left(\right.$ in $\left.\mathrm{hPa}(100 \mathrm{~km})^{-1}\right)$; gradPmax: maximum MSLP gradient (in hPa $\left.(100 \mathrm{~km})^{-1}\right)$; Glat, Glon: location of the maximum MSLP gradient; Pmin: minimum pressure (in hPa), LapP: maximum Laplacian of MSLP (in hPa (deg. lat.) ${ }^{-2}$ ); Llat, Llon: location of the maximum Laplacian of MSLP; GP: number of NCEP-1 grid points over Continental Europe showing the exceedance of the long term 98th percentile of daily maximum wind speed; Damage: associated raw damage (computed as described in Klawa and Ulbrich, 2003; Pinto et al., 2007a). For more details see text.

\begin{tabular}{|c|c|c|c|c|c|c|c|c|c|c|}
\hline Storm & Date & $\operatorname{gradP} 1$ & $\operatorname{gradP} 2$ & gradPmax & Glat, Glon & Pmin & LapP & Llat, Llon & GP & Damage \\
\hline Daria & 25 Jan 1990 & 0.84 & 0.52 & 1.73 & $60.0^{\circ} \mathrm{N} ; 15.0^{\circ} \mathrm{W}$ & 947.0 & 3.43 & $56.1^{\circ} \mathrm{N} ; 2.0^{\circ} \mathrm{E}$ & 96 & 1890.3 \\
\hline Herta & 03 Feb 1990 & 0.78 & 0.72 & 1.72 & $52.5^{\circ} \mathrm{N} ; 2.5^{\circ} \mathrm{E}$ & 992.1 & 1.85 & $52.8^{\circ} \mathrm{N} ; 5.6^{\circ} \mathrm{E}$ & 52 & 249.0 \\
\hline Judith & 08 Feb 1990 & 0.88 & 0.47 & 1.48 & $45.0^{\circ} \mathrm{N} ; 12.5^{\circ} \mathrm{W}$ & 977.4 & 1.41 & $58.1^{\circ} \mathrm{N} ; 12.9^{\circ} \mathrm{E}$ & 83 & 347.8 \\
\hline Vivian & 26 Feb 1990 & 0.77 & 0.38 & 1.45 & $62.5^{\circ} \mathrm{N} ; 7.5^{\circ} \mathrm{E}$ & 947.7 & 2.38 & $57.9^{\circ} \mathrm{N} ; 4.9^{\circ} \mathrm{E}$ & 107 & 1386.1 \\
\hline Wiebke & 01 Mar 1990 & 0.99 & 0.77 & 1.65 & $55.0^{\circ} \mathrm{N} ; 2.5^{\circ} \mathrm{E}$ & 975.3 & 1.48 & $53.1^{\circ} \mathrm{N} ; 10.3^{\circ} \mathrm{E}$ & 84 & 810.2 \\
\hline Anatol & 04 Dec 1999 & 0.36 & 0.57 & 1.30 & $60.0^{\circ} \mathrm{N} ; 10.0^{\circ} \mathrm{E}$ & 957.7 & 3.37 & $57.5^{\circ} \mathrm{N} ; 16.4^{\circ} \mathrm{E}$ & 87 & 1209.6 \\
\hline Lothar & 26 Dec 1999 & 0.13 & 0.44 & 1.00 & $45.0^{\circ} \mathrm{N} ; 15.0^{\circ} \mathrm{E}$ & 961.0 & 1.16 & $49.1^{\circ} \mathrm{N} ; 0.7^{\circ} \mathrm{E}$ & 73 & 1163.9 \\
\hline Martin & 26 Dec 1999 & 0.30 & 0.53 & 0.95 & $47.5^{\circ} \mathrm{N} ; 5.0^{\circ} \mathrm{W}$ & 971.6 & 2.68 & $47.5^{\circ} \mathrm{N} ; 1.4^{\circ} \mathrm{W}$ & 89 & 2036.1 \\
\hline Jeanette & 27 Oct 2002 & 0.35 & 0.32 & 1.32 & $45.0^{\circ} \mathrm{N} ; 40.0^{\circ} \mathrm{W}$ & 972.9 & 2.73 & $55.8^{\circ} \mathrm{N} ; 4.6^{\circ} \mathrm{E}$ & 87 & 1503.9 \\
\hline Kyrill & 18 Jan 2007 & 0.48 & 0.69 & 1.49 & $55.0^{\circ} \mathrm{N} ; 15.0^{\circ} \mathrm{E}$ & 961.7 & 2.10 & $55.2^{\circ} \mathrm{N} ; 20.8^{\circ} \mathrm{E}$ & 127 & 4811.4 \\
\hline
\end{tabular}

\section{Comparison to previous storms}

In order to compare Kyrill's intensity and its associated surface wind fields with other selected storms, we have compared Kyrill's track, MSLP characteristics, and associated storm damage with the nine most intense, recent winter storms since 1990. These storm events and related features are listed in Table 1. The absolute minimum core pressure for each storm (cf. Table 1, column 7) corresponds to the results from the tracking algorithm (Murray and Simmonds, 1991; Pinto et al., 2005), except for Lothar, for which the minimum observed station value of $961 \mathrm{hPa}$ is given. Lothar was a small-size and fast-moving system, and both the NCEP1 and ERA-40 reanalyses underestimate its core pressure significantly (e.g., Ulbrich et al., 2001, their Fig. 1). As is evident from the Table 1, Kyrill's minimum MSLP of $962 \mathrm{hPa}$ ranks only as the fifth lowest. Two of the five cyclones that occurred in January and February 1990, Daria (alternatively known as the "Burns Day Storm") and Vivian had core pressure values below $950 \mathrm{hPa}$. In terms of the Laplacian of MSLP, which is proportional to relative vorticity and is an indicator of the intensity of the circulation associated with a cyclone (cf. Murray and Simmonds, 1991), Kyrill's value of $2.10 \mathrm{hPa}$ (deg. lat.) $)^{-2}$ is only six largest (cf. Table 1). The corresponding values for Daria and Anatol, a cyclone that swept across the North and Baltic Seas in early December 1999 and featured a minimum core pressure of $958 \mathrm{hPa}$ (cf. Fig. 8d), are $3.43 \mathrm{hPa}$ (deg. lat.) ${ }^{-2}$ and $3.37 \mathrm{hPa}$ (deg. lat.) $)^{-2}$, respectively. Hence, the "circulation/vorticity anomaly" associated with Kyrill was by far not the strongest among the ten selected storms.

Clearly, and to a first order approximation, it is the pressure gradient that determines the (geostrophic) wind speed and associated damage and not the absolute pressure value.
Thus, not surprisingly, a typical characteristic of the most strong winter storms is their occurrence in periods with an anomalously high meridional pressure gradient over the eastern North Atlantic and Western Europe, as documented for Kyrill in Fig. 1. However, the areal extents and intensity of the pressure gradient will depend on the pre-existing pressure gradient and the extent to which the cyclone further tightens the surface isobars. To test this hypothesis, we analysed the 15-, 9-, and 5-day averaged pressure gradient anomaly before the "landfall" in Western Europe for each of the storms listed in Table 1 with respect to the 1958-2005 reference period. Landfall is defined here as the calendar day when the cyclone crossed the $10^{\circ} \mathrm{W}$ meridian. For example, this means that since Kyrill crossed the $10^{\circ} \mathrm{W}$ meridian during 18 January 2007 , the pressure gradient anomaly map was constructed for the period 9 to 17 January 2007. Even though results depend on the pre-storm average period and the history of cyclonic activity within it, some consistent features regarding the magnitude and location of the pressure gradient can be inferred. For example, storm Lothar in December 1999 only had a very weak MSLP gradient anomaly within the "East Atlantic" and "Central European" regional boxes (Table 1) displayed in Fig. 8a and the weakest maximum pressure gradient of all ten winter storms (Table 1, see also supplementary electronic material, http://www.nat-hazards-earth-syst-sci.net/ 9/405/2009/nhess-9-405-2009-supplement.pdf). This can only partly be explained by the fact that a strong zonal jet stream over the eastern North Atlantic Ocean was not observed until three days before landfall. Lothar was a very small storm and underwent explosive development close to the European coastline (Ulbrich et al., 2001). Note that the also "small-diameter" successor storm of Lothar, Martin, had similar characteristics in terms of observed pressure gradi- 


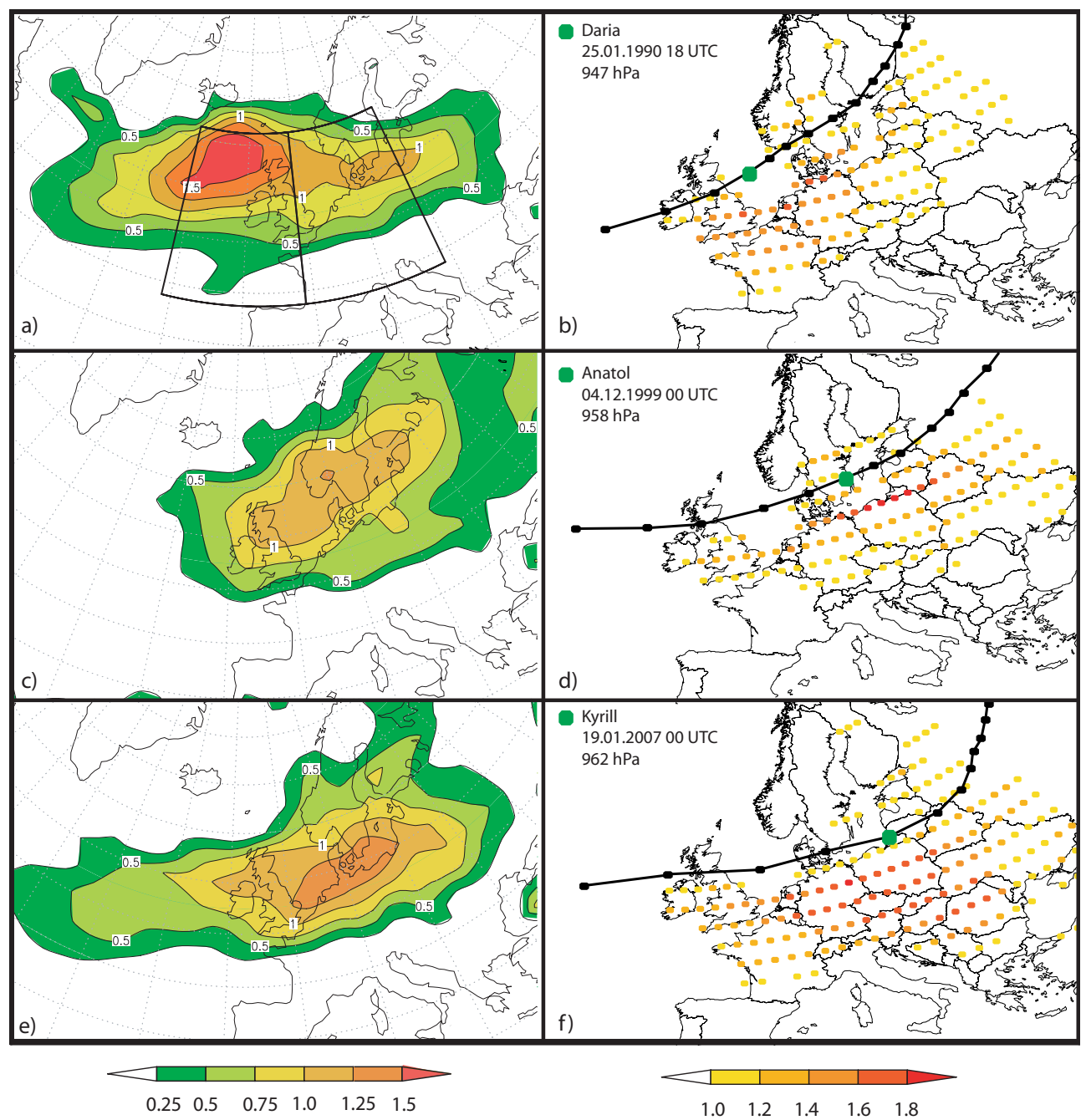

Fig. 8. Pre-existing MSLP gradient, cyclone path, and associated surface winds for three storms over Europe: Daria (a-b), Anatol (c-d), and Kyrill (e-f). Left panels show the pre-existing average MSLP gradient (in $\mathrm{hPa}(100 \mathrm{~km})^{-1}$ ) for nine days before crossing the $10^{\circ} \mathrm{W}$ longitude. Right panels show cyclone tracks and associated wind fields based on NCEP-1 reanalysis data. Black dots indicate the six-hourly storm position. The green dots correspond to the position with lowest core pressures. The remaining dots show the fractional exceedance of the 98th wind speed percentile for December to February 1958-2005 by the maximum surface winds observed during the storm passage. The two boxes in (a) are used for the calculation of the MSLP gradients (cf. Table 1). For more details see text.

ents. On the other hand, the 9-day averaged pre-storm pressure gradient anomaly for Daria was stronger than for Kyrill, but the largest gradients were located over the North Atlantic west of the British Isles and not exactly over Europe like in the case of Kyrill (Fig. 8). Further, the strongest pressure gradient anomalies for Anatol, that had a similar track across Europe than Kyrill (Fig. 8d and f), were also located around $0^{\circ} \mathrm{W}$, but were of weaker magnitude (Fig. 8c and e). This is a clear indication of the role of the MSLP gradient for the development of storm Kyrill. In order to assess the integrative strength of the wind field and associated storm damage, we extracted the daily maximum surface $(10 \mathrm{~m})$ wind speed from the gridded NCEP-1 reanalysis data during the three-day periods when the investigated ten storms crossed Europe. Lothar was an exception in that it was followed about $24 \mathrm{~h}$ later by Martin and the observation window had to be cut down to $36 \mathrm{~h}$ to obtain the wind speeds caused only by this storm. Next, the maximum stormrelated wind speed values at each grind point were normalized with the corresponding 98th percentile of daily maximum local surface winds for the period December/February 1958/59-2004/05. The 98th percentile value in $\mathrm{m} \mathrm{s}^{-1}$ is the threshold above which only $2 \%$ of the surface wind speeds are located in the reference period 1958-2005, and corresponds to the minimum wind speed above which losses may be expected (cf. Klawa and Ulbrich, 2003). It is evident from Fig. $8 \mathrm{f}$ that Kyrill affected a quite large area of Europe with many grid points experiencing a $40 \%$ exceedance of the 
98th percentile of daily maximum wind speed. A comparison with some of the strongest storms in terms of core pressure, Daria and Anatol (the latter possessing a similar track and also affecting Eastern Europe) discloses that the area of damaging winds associated with Kyrill is not only larger, but also more intense regarding the overall percentage exceedance of the 98th percentile at the grid points. This finding is corroborated by the last two columns of the Table 1. The number of grid points (GP) at which the 98th percentile was exceeded during Kyrill's passage is by far the largest of all ten recent strong winter storms. The prominence of Kyrill is also striking when estimating the storm's "raw damage". The latter is assessed by calculating the cube of the positive difference between the observed maximum wind speed and the 98th percentile of daily maximum wind speed for each land grid point, weighting it with the corresponding population density (as a proxy for the insured values in each area), and summing it up for all grid points (cf. Pinto et al., 2007a, Sect. 3.1). With respect to the "raw damage" values, Kyrill is more than twice as strong as the next strongest storm Martin (Table 1).

Finally, Fig. 8 enables a comparison between the degree of the exceedance of the 98th wind speed percentile value and the pre-existing pressure gradient anomaly, showing that the former is maximised over the area of the more intense values of the latter. This is suggestive of the notion that the largest wind speeds and damages occur in the area where the passing cyclone further tightens the ambient pressure gradients. We conclude that one factor that leads to Kyrill's large impact is the strong background pressure gradient anomaly located over Central Europe and stretching into Eastern Europe. This finding may also help to assess the potential of damaging winter cyclones in a future, anthropogenically changed climate. This aspect will be analysed and discussed in the next section.

\section{Climate change considerations}

Climate change studies with the ECHAM5 suggest an enhanced frequency of storms tracking from the North Atlantic Ocean into the North Sea and further into the Baltic Sea at the end of this century. This is associated with a more frequent eastward extension of the polar jet into Europe than under present climate conditions (e.g., Pinto et al., 2007b, 2009). These results agree with the IPCC 4AR (cf. Meehl et al., 2007). The report concludes that it seems "more likely than not" that extreme wind speeds in Northern Europe will increase. It shall be emphasized that ECHAM5 is one of the GCMs included in the IPCC 4AR that is closest to the ensemble mean in terms of the changes of storm track activity (Ulbrich et al., 2008). Figure 9 shows the Northern Hemisphere MSLP and MSLP gradient fields for the control period (1970-1999) from the $20 \mathrm{C}$ realisations as well as the changes to the projected future climate (2070-
2099) taken from the IPCC A1B scenario. Figure 9c displays a statistically significant enhancement of surface pressure across the Mediterranean and a lowering around Greenland and the Canadian Arctic. This in part corresponds to a northeastward shift of the Azores High and an enhanced Icelandic Low (Fig. 9a). An enhanced NAO and a north-eastward shift of its poles with increasing GHG forcing have been found elsewhere (e.g., Ulbrich and Christoph, 1999; Stephenson et al., 2006; Pinto et al., 2007b). However, as shown here, this is associated with a significant increase in the climatological MSLP gradient field stretching from the Eastern North Atlantic Ocean across the British Isles, the Southern North Sea, and Denmark into the Southern Baltic Sea (Fig. 9d). This is exactly the area in which large parts of the tracks of Kyrill, Anatol, and Daria are located in (Fig. 8, right panels). Thus, the published and results presented herein suggest that a stronger polar jet over Western Europe may steer more storms into the area of which some may have a stronger impact due to a pre-existing, enhanced "background" pressure gradient. These results are in line with the enhanced frequency of wind storms and increased loss potentials over Europe identified by Leckebusch et al. (2007) and Pinto et al. (2007a).

Hitherto, the majority of the published results on future changes in storm frequency and intensity are based on output from coarse resolution global climate models. In order to expand research to regional details and impacts in Central Europe, we used REMO (Jacob, 2005a,b) and COSMOCLM (Keuler et al., 2006; Keuler and Lautenschlager, 2006) simulations nested into the ECHAM5 for recent climate conditions (control period) and for the SRES A1B scenario. These models are able to reproduce the climate characteristics and interannual variability when forced with reanalysis data (cf. Jacob et al., 2007; Jaeger et al., 2008; Roesch et al., 2008). Maps for the 98th percentile of the daily maximum wind speed for the control period (1970-1999) exhibit the strong dependence of this parameter on the surface roughness, i.e. the land use (not shown). However, since the surface roughness is constant over the climate change simulation period, the climate change signal for the A1B scenario is assessed from the changes in the 98th percentile wind speed value between 2070 and 2099 and the control period. The COSMO-CLM shows an increase of the 9th percentile of the daily surface maximum wind speed of $5-15 \%$ over most of Europe (Fig. 10a), thus indicating an enhanced risk of occurrence of wind storms. The largest values are found over Benelux, Germany, and Poland. Over Northern Scandinavia and parts of the Mediterranean, changes are small or even of negative sign. The corresponding figure for the REMO projection (Fig. 10b) shows an enhanced risk of occurrence of winter storms over Central Europe, particularly over the North Sea and the Baltic Sea coast, as well as in parts of North-Eastern Germany and North-Western Poland. 

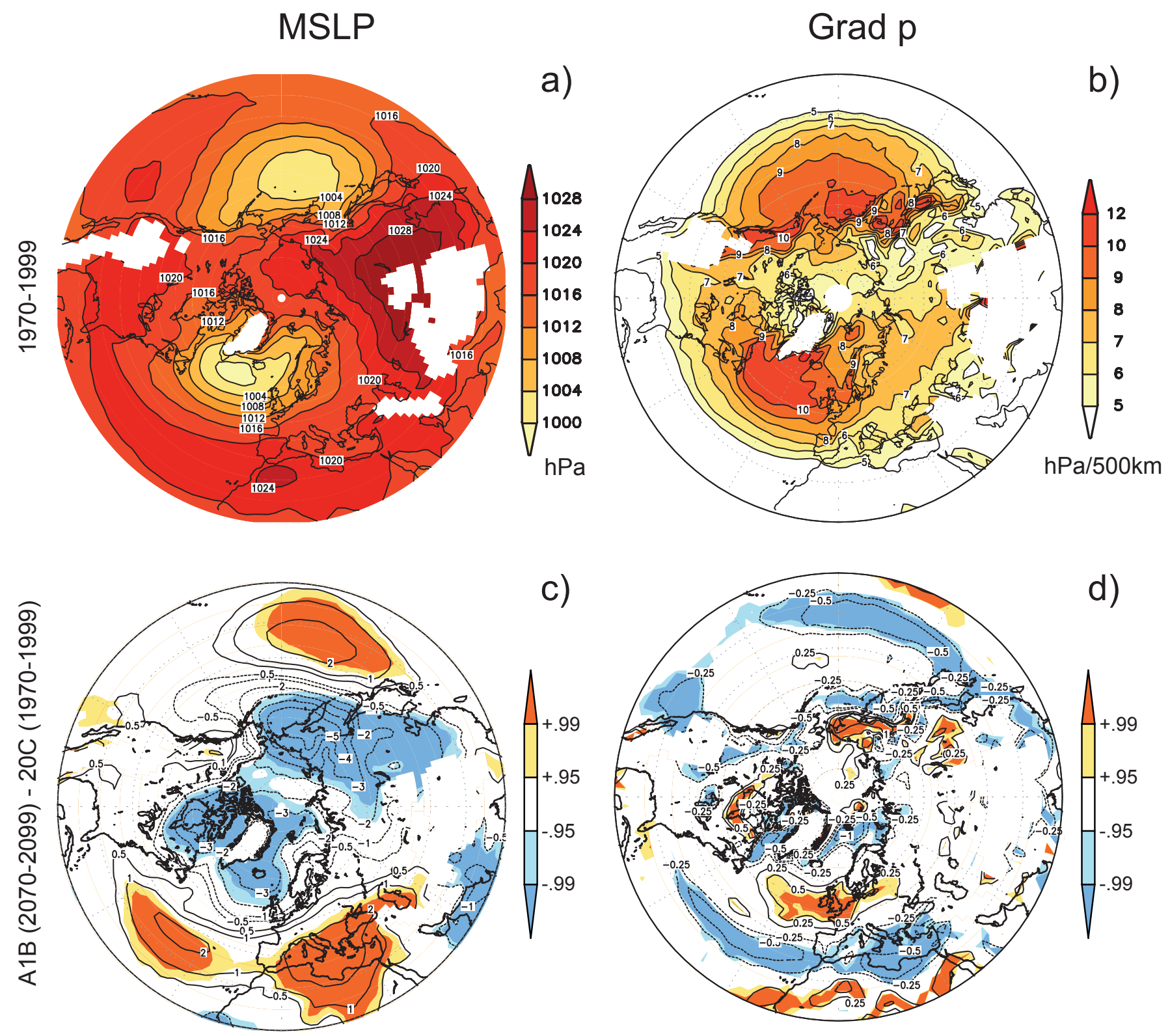

Fig. 9. MSLP and MSLP gradient for January based on ECHAM5 ensemble simulations. (a) MSLP for January 1970-1999 (20C) based on three ensemble simulations. (b) As in (a), but for MSLP gradient. (c) Changes in MSLP between A1B and 20C ensemble average (2070/2099-1970/1999). (d) As in (c) but for MSLP gradient. Areas with significant differences at the 95th and 99th confidence levels, based on a two-sided student t-test for monthly values, are coloured in (c) and (d). Areas higher than $1500 \mathrm{~m}$ have been omitted.

Even though the relative changes in REMO are smaller when compared to COSMO-CLM, the absolute wind speed increases are similar, since REMO simulates a higher 98th percentile for the present day climate (not shown).
Thus, not surprisingly, the dynamical downscaling with REMO and COSMO-CLM corroborates the findings achieved with the ECHAM5 studies (e.g., Pinto et al., 2007a), though with more regional details. The different magnitude of the relative changes for REMO and COSMOCLM are similar to previous results obtained by other regional climate models forced with the same GCM (e.g., Leckebusch et al., 2006). 


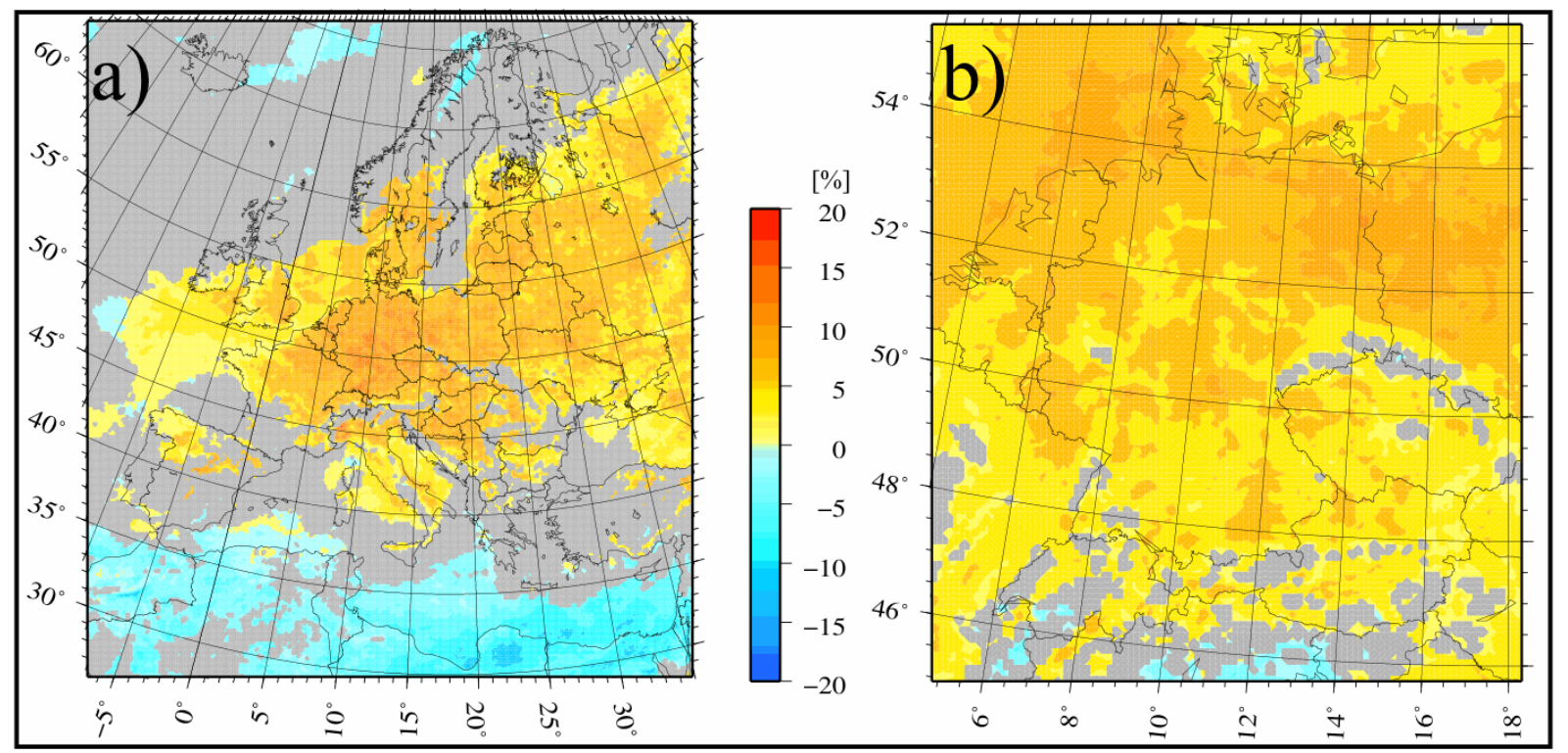

Fig. 10. A1B-based climate change signal (2070-2099 minus 1970-1999) for the relative differences (in \%) of the 98th percentile of the daily maximum surface wind speed (October to March). Results for COSMO-LM are shown in (a) and for REMO in (b). Non-significant changes are in grey, whereas colours indicate significant (95th confidence level) regions based on a two-sided student t-test.

\section{Summary and concluding remarks}

The present study describes the synoptic evolution and some meteorological impacts of the European winter storm Kyrill that swept across Western, Central, and Eastern Europe between 17 and 19 January 2007. It aimed at elaborating on synoptic and mesoscale environmental and storm features that explain the intensity and large storm damage associated with Kyrill. A particular aspect was the comparison to the nine most intense recent winter storms since 1990 and how a pre-existing MSLP gradient anomaly impacted on the observed surface wind speeds. Output from a global climate model and two state-of-the-art regional climate models has been used to assess the intensity of extreme storms in an anthropogenically changed climate at the end of this century.

Kyrill appeared on a weather map over the Southern Mississippi valley about four days before it hit Europe. It underwent an explosive intensification over the Western Atlantic while crossing a very intense zonal jet stream. The region is well known for frequent explosive cyclogenesis (Sanders and Gyakum, 1980; Roebber, 1984; Sanders, 1986; MacDonald and Reiter, 1988). A secondary cyclone developed near Kyrill I's occlusion point and it is speculated here that without this formation of a new cyclonic centre, Kyrill would have slowed down and decayed over the North Atlantic without affecting Europe. The strong zonal polar jet stream steered Kyrill II not only towards Europe, but a superposition of several favourable meteorological conditions to the west of the British Isles likely caused a further slow deepening of the storm when it started to affect Western Europe. Lothar in December 1999, for example, belonged to another "type" of storms in that it crossed the strong Atlantic jet stream and underwent an explosive development not until it was close to "landfall" in Western Europe (Ulbrich et al., 2001). Evidence is provided that a favourable alignment of three polar jet streaks and a dry air intrusion over the occlusion and cold fronts were causal factors in maintaining Kyrill II's low pressure very far into Eastern Europe. It is pointed out that, over East Germany, the deep convection and the resulting strong rainfall, as well as lightning activity during the passage of the cold front were likely caused by the upper-level dry air. Whereas the destabilisation of the lower troposphere and the associated downward mixing of momentum along the cold front seem to be a general mesoscale mechanism to enhance Kyrill II's surface winds, convective downdrafts over East Germany may have further intensified the gustiness locally.

Given the likely importance of the secondary frontal wave cyclogenesis for the storm losses in Europe, a much more detailed study of the formation of Kyrill II is desirable. As pointed out in Parker (1998), however, the incipient wave grows as a mesoscale feature at low-levels involving boundary layer dynamics. Thus a mesoscale model forced with (re-)analysis data is the most promising approach to obtain a deeper insight. The mesoscale modelling approach is also mandatory to more quantitatively assess the roles of the meteorological factors that maintained Kyrill II's deep core MSLP values deep into Europe. As pointed out by Uccellini (1990), forcing factors of cyclogenesis interact nonlinearly, over small areas, or over a limited period during the storm development. Kyrill is also an exceptional example to 
study how mesoscale, anomalously intense convective storm features in the vicinity of a cold front, not resolved in regional climate models, and, even not, in many weather forecast models, can considerably augment the peak gusts. In this context, the consideration of the statistical relation of observed MSLP gradients and low-level static stability vs. the observed gustiness may help in operational forecasts and climate change studies on future storm losses.

The detailed analysis of Kyrill and a comparison with previous storms suggest that the storm was embedded in an anomalously strong, pre-storm MSLP gradient field and possessed an unusual swath width of gale force winds. This and its deep penetration into Eastern Europe were among the factors that caused the large storm loss in Europe. Since some of the meteorological factors associated with Kyrill, namely a strong eastern Atlantic jet stream and a very humid and warm air mass in the storm's warm sectors (e.g., Pinto et al., 2009), as well as an enhanced pre-existing pressure gradient (cf. Sect. 4) are projected to occur more frequently at the end of this century, the frequency of occurrence of damaging storms may be expected to increase in the future. Results from one IPCC SRES A1B scenario realisations of REMO and COSMO-CLM, respectively, unveil, among other regional details, that also eastern parts of Central Europe could experience a significant increase in storminess at the end of this century. The credibility and uncertainty range of the regional changes in surface wind speed shall be, however, verified with a multi-model, multi-ensemble approach, like the one currently being pursued in the European Union Framework 6 project ENSEMBLES. As discussed in Sect. 4, Kyrill is one of the hitherto few strong European winter storms that impacted the economically evolving countries of Eastern Europe. Thus, a further diagnosis and the modelling of the mesoscale features of Kyrill may also help to assess future storm losses for the whole of Europe.

Acknowledgements. The authors would like to thank DWD for providing daily data from several climate stations and water vapour satellite images. In particular, we thank J. Asmus (DWD) for assistance with the satellite images. We also thank M. Reyers, S. Ulbrich, P. Ludwig, and M. K. Karremann for help in preparing Figs. 1, 2, 8, and 9. We are indebted to A. Reiner for providing information on the economic impacts of Kyrill. We thank the Max-Planck-Institute for Meteorology, the Federal Environmental Agency, and the COSMO-CLM consortium for the permission to use the REMO and COSMO-CLM data. We are grateful to the German Climate Computing Centre (DKRZ) and the World Data Centre for Climate (WDCC), both located in Hamburg (Germany), for providing computer capacity. The Regional Computing Centre (RRZK; Cologne, Germany) furnished computer and storage capacity. We thank H. Wernli and one anonymous reviewer for their comments that helped to greatly improve the manuscript.

Edited by: A. Mugnai

Reviewed by: H. Wernli and another anonymous referee

\section{References}

Baehr, C., Pouponneau, B., Ayrault, F., and Joly, A.: Dynamical characterization of the FASTEX cyclogenesis cases, Q. J. Roy. Meteor. Soc., 125, 3469-3494, 1999.

Bengtsson, L., Hodges, K. I., and Roeckner, E.: Storm tracks and climate change, J. Climate, 19, 3518-3543, 2006.

Berliner Wetterkarte: Jahrgang 56, Nr. 13-14, Publication of the Verein Berliner Wetterkarte, Berlin, ISSN 0177-3984, 2007 (in German).

Böhm, U., Kücken, M., Ahrens, W., Block, A., Hauffe, D., Keuler, K., Rockel, B., and Will, A.: CLM - the Climate Version of LM: Brief Description and long-term Applications, COSMO Newsletter, 6, 225-235, 2006.

Browning, K. A.: The dry intrusion perspective of extra-tropical cyclone development, Meteorol. Appl.,4, 317-324, 1997.

Browning, K. A.: The sting at the end of the tail: Damaging winds associated with extratropical cyclones, Q. J. Roy. Meteor. Soc., 130, 375-399, 2004.

Browning, K. A. and Field, M: Evidence from Meteosat imagery of the interaction of sting jets with the boundary layer, Meteorol. Appl., 11, 277-289, 2004.

Chang, C. B., Pepkey, D. J., and Kreitzberg, C. W.: Latent heat induced energy transformations during cyclogenesis, Mon. Weather Rev., 112, 357-367, 1984.

Christensen, J. H., Hewitson, B., Busuioc, A., Chen, A., Gao, X., Held, I., Jones, R., Kolli, R. K., Kwon, W.-T., Laprise, R., Magaña Rueda, V., Mearns, L., Menéndez, C. G., Räisänen, J., Rinke, A., Sarr, A., and Whetton, P.: Climate Change 2007: The Physical Science Basis, in: Regional Climate Projections, edited by: Solomon, S., Qin, D., Manning, M., Chen, Z., Marquis, M., Averyt, K. B., Tignor, M., and Miller, H. L., Cambridge University Press, Cambridge, UK and New York, USA, 847-940, 2007.

Defant, A.: Die Schwankungen der atmosphärischen Zirkulation über dem Nordatlantischen Ozean im 25-jährigen Zeitraum 1881-1905, Geogr. Ann., 6, 13-41, 1924 (in German).

Deutsche Rück: Sturmdokumentation 1997-2004, Publication of the Deutsche Rück Reinsurance Company, Düsseldorf, 180 pp., http://www.deutsche-rueck.de/web/export/sites/dr/ das_unternehmen/veroeffentlichungen/sturmdokumentation/ index.html, 2005 (in German).

Deutsche Rück: Sturmdokumentation Publication of the Deutsche Rück Reinsurance Company, Düsseldorf, 32 pp., http: //www.deutsche-rueck.de/web/export/sites/dr/das_unternehmen/ veroeffentlichungen/sturmdokumentation/index.html, 2008 (in German).

Friedrich, A. and Kratzsch, T.: Orkan "Kyrill” über Deutschland, Deutscher Wetterdienst, Abteilung Basisvorhersagen, Berichte zu besonderen Ereignissen, Stürme, Publications of the German Weather Service, 21 pp., 2007 (in German).

Gesamtverband der Deutschen Versicherer (GDV): Jahrbuch 2007 - Die deutsche Versicherungswirtschaft, Berlin, 132 pp., http://www.gdv.de/Downloads/Jahrbuch/Jahrbuch_2007_neu.pdf, 2007 (in German).

Hurrell, J. W.: Decadal trends in the North Atlantic Oscillation: regional temperatures and precipitation, Science, 269, 676-679, 1995.

Jacob, D.: A note to the simulation of the annual and interannual variability of the water budget over the Baltic Sea drainage basin, Meteorol. Atmos. Phys., 77, 61-73, 2001. 
Jacob, D.: REMO Climate of the 20th Century Run, UBA Project, 0.088 Degree Resolution, run no. 006210, 1H DATA, World Data Center for Climate, CERA-DB "REMO_UBA_C20_1_R006210_1H", http://cera-www.dkrz.de/WDCC/ui/Compact.jsp?acronym= REMO_UBA_C20_1_R006210_1H, 2005a.

Jacob, D.: REMO A1B Scenario Run, UBA Project, 0.088 Degree Resolution, run no. 006211, 1H DATA, World Data Center for Climate, CERA-DB "REMO_UBA_A1B_1_R006211_1H", http://cera-www.dkrz.de/WDCC/ui/Compact.jsp?acronym= REMO_UBA_A1B_1_R006211_1H, 2005b.

Jacob, D., Bäring, L., Christensen, O. B., Christensen, J. H., de Castro, M., Déqué, M., Giorgi, F., Hagemann, S., Hirschi, M., Jones, R., Kjellström, E., Lenderink, G., Rockel, B., Sánchez, E., Schär, C., Seneviratne, S. I., Somot, S., van Ulden, A., and van den Hurk, B.: An inter-comparison of regional climate models for Europe: model performance in present day climate, Climatic Change, 81, 31-52, doi:10.1007/s10584-006-9213-4, 2007.

Jaeger, E. B., Anders, I., Lüthi, D., Rockel, B., Schär, C., and Severiatne, S. I.: Validation of ENSEMBLES CLM model simulations for Europe forced by ERA40, Meteorol. Z., 17, 349-367, 2008.

Jones, P. D., Jonsson, T., and Wheeler, D.: Extension to the North Atlantic Oscillation using early instrumental pressure observations from Gibraltar and South-West Iceland, Int. J. Climatol., 17, 1433-1450, 1997.

Kalnay, E., Kanamitsu, M., Kistler, R., Collins, W., Deaven, D., Gandin, L., Iredell, M., Saha, S., White, G., Woollen, J., Zhu, Y., Leetmaa, A., Reynolds, B., Chelliah, M., Ebisuzaki, W., Higgins, W., Janowiak, J., Mo, K. C., Ropelewski, C., Wang, J., Jenne, R., and Joseph, D.: The NCEP-NCAR 40-Year Reanalysis Project, B. Am. Meteorol. Soc., 77, 437-472, 1996.

Keuler, K., Lautenschlager, M., Wunram, C., and Keup-Thiel, E.: Climate Simulation with CLM, Climate of the 20th Century run no.1, Data Stream 2: European region MPI-M/MaD, World Data Center for Climate, BCERA-DB, "CLM C20 1 D2", doi:10.1594/WDCC/CLM_C20_1_D2, 2006.

Keuler, K. and Lautenschlager, M.: Climate Simulation with CLM, Scenario A1B run no.1, Data Stream 2: European region MPI-M/MaD, World Data Center for Climate, CERA-DB “CLM_A1B_1_D2”, http://cera-www.dkrz.de/ WDCC/ui/Compact.jsp?acronym=CLM_A1B_1_D2, 2006.

Klawa, M. and Ulbrich, U.: A model for the estimation of storm losses and the identification of severe winter storms in Germany, Nat. Hazards Earth Syst. Sci., 3, 725-732, 2003, http://www.nat-hazards-earth-syst-sci.net/3/725/2003/.

Lambert, S. and Fyfe, J. C.: Changes in winter cyclone frequencies and strengths simulated in enhanced greenhouse gas experiments: Results from the models participating in the IPCC diagnostic exercise, Clim. Dynam., 26, 713-728, 2006.

Leckebusch, G. C., Koffi, B., Ulbrich, U., Pinto, J. G., Spangehl, T., and Zacharias, S.: Analysis of frequency and intensity of winter storm events in Europe on synoptic and regional scales from a multi-model perspective, Climate Res., 31, 59-74, 2006.

Leckebusch, G. C., Ulbrich, U., Fröhlich, L., and Pinto, J. G.: Property loss potentials for European midlatitude storms in a changing climate, Geophys. Res. Lett., 34, L05703, doi:10.1029/2006GL027663, 2007.

Luterbacher, J., Liniger, M. A., Menzel, A., Estrella, N., Della-
Marta, P. M., Pfister, C., Rutishauser, T., and Xoplaki, E.: Exceptional European warmth of autumn 2006 and winter 2007: Historical context, the underlying dynamics, and its phenological impacts, Geophys. Res. Lett., 34, L12704, doi:10.1029/2007GL029951, 2007.

MacDonald, B. C. and Reiter, E. A.: Explosive cyclogenesis over the Eastern United States, Mon. Weather Rev., 116, 1568-1586, 1988.

Meehl, G. A., Stocker, T. F., Collins, W. D., Friedlingstein, P., Gaye, A. T., Gregory, J. M., Kitoh, A., Knutti, R., Murphy, J. M., Noda, A., Raper, S. C. B., Watterson, I. G., Weaver, A. J., and Zhao, Z.-C.: Global Climate Projections, in: Climate Change 2007: The Physical Science Basis. Contribution of Working Group I to the Fourth Assessment Report of the Intergovernmental Panel on Climate Change, edited by: Solomon, S., Qin, D., Manning, M., Chen, Z., Marquis, M., Averyt, K. B., Tignor, M., and Miller, H. L., Cambridge University Press, Cambridge, UK and New York, NY, USA, 747-846, 2007.

MunichRe: Winter storms in Europe (II) - Analysis of 1999 losses and loss potentials, Publication of Munich Reinsurance Company, 72 pp., http://www.munichre.com/publications/ 302-03109_en.pdf, 2001.

MunichRe: Topics Geo Naturkatastrophen 2007 - Analysen, Bewertungen, Positionen, Publication of Munich Reinsurance Company, 50 pp., http://www.munichre.com/publications/ 302-05698_de.pdf, 2008(in German).

Murray, R. J. and Simmonds, I.: A numerical scheme for tracking cyclone centres from digital data, Part I: development and operation of the scheme, Aust. Meteorol. Mag., 39, 155-166, 1991.

Nakićenović, N., Alcamo, J., Davis, G., de Vries, B., Fenhann, J., Gaffin, S., Gregory, K., Grübler, A., Jung, T. Y., Kram, T., La Rovere, E. L., Michaelis, L., Mori, S., Morita, T., Pepper, W., Pitcher, H., Price, L., Raihi, K., Roehrl, A., Rogner, H.-H., Sankovski, A., Schlesinger, M., Shukla, P., Smith, S., Swart, R., van Rooijen, S., Victor, N., and Dadi, Z.: Emission scenarios. A Special Report of Working Group III of the Intergovernmental Panel on Climate Change, Cambridge University Press, 599 pp., 2000.

Ogi, M., Yamazaki, K., and Tachibana, Y.: The summertime annular mode in the Northern Hemisphere and its linkage to the winter mode, J. Geophys. Res., 109, D20114, doi:10.1029/2004JD004514, 2004.

Parker, D. J.: Secondary frontal waves in the North Atlantic region: A dynamical perspective of current ideas, Q. J. Roy. Meteor. Soc., 124, 829-856, 1998.

Pinto, J. G., Spangehl, T., Ulbrich, U., and Speth, P.: Sensitivities of a cyclone detection and tracking algorithm: individual tracks and climatology, Meteorol. Z., 14, 823-838, 2005.

Pinto, J. G., Fröhlich, E. L., Leckebusch, G. C., and Ulbrich, U.: Changing European storm loss potentials under modified climate conditions according to ensemble simulations of the ECHAM5/MPI-OM1 GCM, Nat. Hazards Earth Syst. Sci., 7, 165-175, 2007a, http://www.nat-hazards-earth-syst-sci.net/7/165/2007/.

Pinto, J. G., Ulbrich, U., Leckebusch, G. C., Spangehl, T., Reyers, M., and Zacharias, S.: Changes in storm track and cyclone activity in three SRES ensemble experiments with the ECHAM5/MPI-OM1 GCM, Clim. Dynam., 29, 195-210, $2007 \mathrm{~b}$.

Pinto, J. G., Zacharias, S., Fink, A. H., Leckebusch, G. C., and U1- 
brich, U.: Environmental factors contributing to the development of extreme cyclones and their relationship with NAO, Clim. Dynam., 32, 711-737, 2009.

Raible, C. C., Della-Marta, P., Schwierz, C., Wernli, H., and Blender, R.: Northern Hemisphere extratropical cyclones: A comparison of detection and tracking methods and different reanalyses, Mon. Weather Rev., 136, 880-897, 2008.

Roebber, P. J.: Statistical analysis and updated climatology of explosive cyclones, Mon. Weather Rev., 112, 1577-1589, 1984.

Roeckner, E., Bäuml, G., Bonaventura, L., Brokopf, R., Esch, M., Giorgetta, M., Hagemann, S., Kirchner, I., Kornblueh, L., Manzini, E., Rhodin, A., Schlese, U., Schulzweida, U., and Tompkins, A.: The atmospheric general circulation model ECHAM 5., Part I: Model description, Max-Planck Institute, Hamburg, Germany, Report no. 349, 127 pp., 2003.

Roeckner, E., Brokopf, R., Esch, M., Giorgetta, M., Hagemann, S., Kornblueh, L., Manzini, E., Schlese, U., and Schulzweida, U.: Sensitivity of Simulated Climate to Horizontal and Vertical Resolution in the ECHAM5 Atmosphere Model, J. Clim., 19, 3771-3791, 2006.

Roesch, A., Jaeger, E. B., Lüthi, D., and Seneviratne, S. I.: Analysis of CLM model biases in relation to intraensemble model variability, Meteorol. Z., 17, 369-382, 2008.

Sanderson, B. and Brassington, G.: Fourth-and Fifth-order finitedifference methods applied to a control-volume ocean model, J. Atmos. Ocean. Tech., 19, 1424-1441, 2002.

Sanders, F. and Gyakum, J. R.: Synoptic-dynamic climatology of the "bomb", Mon. Weather Rev., 108, 1589-1606, 1980.

Sanders, F.: Explosive cyclogenesis in the West-Central North Atlantic Ocean, 1981-84, Part I: composite and mean behavior, Mon. Weather Rev., 114, 1781-1794, 1986.

Scheuren, J. M., le Polain de Waroux, O., Below, R., Guha-Sapir, D., and Ponserre, S.: Annual disaster statistical review: the numbers and trends 2007, Centre for Research on the Epidemiology of Disasters (CRED), Brussels, Belgium, 47 pp., 2008.

Schmetz, J. and Turpeinen, O. M.: Estimation of the uppertropospheric relative humidity field from Meteosat water vapor image data, J. Appl. Meteorol., 27, 889-899, 1988.

Stephenson, D. B., Pavan, V., Collins, M., Junge, M. M., and Quadrelli, R.: Participating CMIP2 Modelling Groups: North Atlantic Oscillation response to transient greenhouse gas forcing and the impact on European winter climate: a CMIP2 multimodel assessment, Clim. Dynam., 27, 401-420, 2006.
Swiss Re: Storm over Europe - An underestimated risk, Swiss Re publishing, Zürich, 27 pp., http://www.swissre.com/resources/ cb941100455c7c57b604be80a45d76a0-storms_europe.Paras. 0003.File.pdf, 2000.

Swiss Re: Natural catastrophes and man-made disasters in 2007: high losses in Europe, Sigma, no. 1/2008, Swiss Re publishing, Zürich, 44 pp., http://www.swissre.com/resources/ 4614e40048e8246184d1ac983ae020a8-Sigma_1_08_e.pdf, 2008.

Tibaldi, S. and Molteni, F.: On the operational predictability of blocking, Tellus, 42A, 343-365, 1988.

Uccellini, L. W. and Johnson, D. R.: The coupling of upper and lower tropospheric jet streaks and implications for the development of severe convective storms, Mon. Weather Rev., 107, 682703, 1979.

Uccellini, L. W.: Process contributing to the rapid development of extratropical cyclones, in: Extratropical Cyclones: The Eric Palmen Memorial Volume, edited by: Newton, C. and Holopainen, E., Am. Meteorol. Soc., 81-107, 1990.

Ulbrich, U. and Christoph, M.: A Shift of the NAO and Increasing Storm Track Activity over Europe due to Anthropogenic Greenhouse Gas Forcing, Clim. Dynam., 15, 551-559, 1999.

Ulbrich, U., Fink, A. H., Klawa, M., and Pinto, J. G.: Three extreme storms over Europe in December 1999, Weather, 56, 7080, 2001.

Ulbrich, U., Pinto, J. G., Kupfer, H., Leckebusch, G. C., Spangehl, T., and Reyers, M.: Northern Hemisphere Storm Tracks in an ensemble of IPCC climate change simulations, J. Climate, 21, 1669-1679, 2008.

Ulbrich, U., Leckebusch, G. C., and Pinto, J. G.: Cyclones in the present and future climate: a review, Theor. Appl. Climatol., published online, doi:10.1007/s00704-008-0083-8, 2009.

Walker, G. T.: Correlation of seasonal variations in weather IX: A further study of world weather, Mem. Indian Meteor. Dep., 25, 275-332, 1924.

Wernli, H., Dirren, S., Liniger, M. A., and Zillig, M.: Dynamical aspects of the life-cycle of the winter storm "Lothar" (24-26 December 1999), Q. J. Roy. Meteor. Soc., 128, 405-429, 2002.

Young, M. V. and Grahame, N. S.: Forecasting the Christmas Eve storm 1997, Weather, 54, 382-391, 1999. 